\title{
Nicotine Enhances Excitability of Medial Habenular Neurons via Facilitation of Neurokinin Signaling
}

\author{
Dang Q. Dao, ${ }^{1}$ Erika E. Perez, ${ }^{1}$ Yanfen Teng, ${ }^{1}$ John A. Dani, ${ }^{1,2}$ and Mariella De Biasi ${ }^{1,2,3}$ \\ ${ }^{1}$ Department of Neuroscience, Baylor College of Medicine, Houston, Texas 77030, and ${ }^{2}$ Department of Neuroscience and ${ }^{3}$ Department of Psychiatry, \\ Perelman School of Medicine at the University of Pennsylvania, Philadelphia, Pennsylvania 19104
}

\begin{abstract}
The medial habenula (MHb) densely expresses nicotinic acetylcholine receptors (nAChRs) and participates in nicotine-related behaviors such as nicotine withdrawal and regulating nicotine intake. Although specific nAChR subunits are identified as being involved in withdrawal behavior, the cellular mechanisms through which nicotine acts to cause this aversive experience is unclear. Here, we demonstrate an interaction between the nicotinic and neurokinin signaling systems that may form the basis for some symptoms experienced during nicotine withdrawal. Using patch-clamp electrophysiology in mouse brain slices, we show that nicotine $(1 \mu \mathrm{M})$ increases intrinsic excitability in MHb neurons. This nicotine-induced phenomenon requires $\alpha 5$-containing nAChRs and depends on intact neurokinin signaling. The effect is blocked by preincubation with neurokinin 1 (NK1; L-732138, $10 \mu \mathrm{M})$ and NK3 (SB222200, $2 \mu \mathrm{M})$ antagonists and mimicked by NK1 (substance P, $100 \mathrm{nM}$ ) and NK3 (neurokinin B [NKB], $100 \mathrm{nM}$ ) agonists. Microinjections (1 $\mu$ l) of L-732138 (50 nM) and SB222200 (100 nM) into the MHb induces withdrawal behavior in chronic nicotine-treated ( $8.4 \mathrm{mg} / \mathrm{kg} / \mathrm{d}, 2 \mathrm{weeks}) \mathrm{mice}$. Conversely, withdrawal behavior is absent with analogous microinjections into the lateral habenula of nicotine-treated mice or in mice chronically treated with a vehicle solution. Further, chronic nicotine reduces nicotine's acute modulation of intrinsic excitability while sparing modulation by NKB. Our work elucidates the interplay between two neuromodulatory signaling systems in the brain through which nicotine acts to influence intrinsic excitability. More importantly, we document a neuroadaptation of this mechanism to chronic nicotine exposure and implicate these mechanisms collectively in the emergence of nicotine withdrawal behavior.
\end{abstract}

Key words: alpha 5 nicotinic subunit; medial habenula; neurokinins; nicotine; electrophysiology; withdrawal

\section{Introduction}

Nicotinic acetylcholine receptors (nAChRs) are found throughout the nervous system, consisting of numerous combinations of $\alpha(\alpha 2-9)$ and $\beta(\beta 2-4)$ subunits in the form of homomeric and heteromeric ion channels (Dani and Bertrand, 2007). In the periphery, nAChRs primarily mediate fast synaptic transmission (Zhang et al., 1996; Ullian et al., 1997), whereas in the CNS, they mostly modulate the function of other neurotransmitter systems (McGehee et al., 1995; Gray et al., 1996; Léna and Changeux, 1997). Nicotine is arguably the primary addictive component in tobacco and its initial actions are via nAChRs (Benowitz, 2009; De Biasi and Dani, 2011). Through genome-wide association studies (GWAS), we now know that increased risk of nicotine dependence in humans is associated with specific single-nucleotide

Received June 26, 2013; revised Jan. 30, 2014; accepted Feb. 8, 2014.

Author contributions: D.Q.D., J.A.D., and M.D.B. designed research; D.Q.D., E.E.P., and Y.T. performed research; D.Q.D., E.E.P., Y.T., and M.D.B. analyzed data; D.Q.D. and M.D.B. wrote the paper.

This work was supported by the National Institute on Drug Abuse-National Institutes of Health (Grants DA017173 and DA029157), the National Cancer Institute-National Institutes of Health (Grant U19CA148127 Area 2 to M.D.B.), and the Diana Helis Henry Medical Research Foundation through its direct engagement in the continuous active conduct of medical research in conjunction with Baylor College of Medicine. We thank Paul Pfaffinger for helpful comments and Peter Reese for technical support.

The authors declare no competing financial interests.

Correspondence should be addressed to Mariella De Biasi, Department of Psychiatry, Perelman School of Medicine at the University of Pennsylvania, 415 Curie Blvd., Philadelphia, PA 19104. E-mail: marielde@mail.med.upenn.edu.

DOI:10.1523/JNEUROSCI.2736-13.2014

Copyright $\odot 2014$ the authors $\quad 0270-6474 / 14 / 344273-12 \$ 15.00 / 0$ polymorphisms located within a particular gene cluster on chromosome 15 that encodes the $\alpha 5, \alpha 3$, and $\beta 4 \mathrm{nAChR}$ subunits (Boulter et al., 1990; Saccone et al., 2007; Berrettini et al., 2008; Bierut et al., 2008; Thorgeirsson et al., 2008). Of these three subunits, $\alpha 5$ has recently received special attention due to its association with various aspects of nicotine dependence, including the number of cigarettes smoked per day (Berrettini et al., 2008) and early onset of nicotine dependence (Weiss et al., 2008), as well as with tobacco-related diseases such as lung cancer (Amos et al., 2008; Thorgeirsson et al., 2008; Wang et al., 2010) and chronic obstructive pulmonary disease (Wang et al., 2010).

The habenulo-interpeduncular ( $\mathrm{Hb}$-IPN) pathway is one of the few areas of the brain where the $\alpha 5, \alpha 3$, and $\beta 4$ subunits are coexpressed (Salas et al., 2004a; Salas et al., 2004b; Salas et al., 2009; Fowler et al., 2011). The Hb-IPN pathway comprises the epithalamic medial $(\mathrm{MHb})$ and lateral habenula ( $\mathrm{LHb})$, the interpeduncular nucleus of the midbrain, and the fasciculus retroflexus, a white matter tract composed predominantly of efferents from the habenula to the IPN and other midbrain nuclei (Sutherland, 1982). The habenula mediates negative reward and motivation (Matsumoto and Hikosaka, 2007, 2009; Frahm et al., 2011; Lammel et al., 2012) and the cholinoceptive MHb in particular plays an important function in nicotine-related behaviors, especially those that are aversive (Salas et al., 2009; Fowler et al., 2011; Frahm et al., 2011). We determined that $\alpha 5$ - and $\beta 4$-containing habenular nAChRs are important for the emergence of nicotine 
withdrawal behavior (Salas et al., 2004a; Salas et al., 2009). Others have shown that habenular nAChRs containing the $\alpha 5$ subunit regulate the consumption of nicotine at normally aversive high doses (Fowler et al., 2011). Regarding the underlying physiology, it is known that habenular cholinergic afferents to the IPN corelease glutamate and acetylcholine to excite IPN neurons via fast and slow transmission modes, respectively (Ren et al., 2011). However, the relationship within the MHb between cholinergic signaling and other neuromodulatory influences that regulate cellular physiology and behavior is unknown (Ebner and Singewald, 2006; Merighi et al., 2011). In this study, we investigated the signaling processes that underlie nicotine-induced neuroadaptations that are the basis for nicotine withdrawal behavior.

\section{Materials and Methods}

Animals. We studied both male and female C57BL/6J mice or nAChR subunit mutant mice $(\alpha 5, \beta 2, \beta 4)$ backcrossed for a minimum of 11 generations into the C57BL/6J background. WT controls and mutant mice were obtained from homozygous breeders that were offspring of heterozygous parents so that both WT and mutant mice had common ancestors. For electrophysiology experiments, mice were used between the ages of postnatal day 17 (P17) and P30. For behavioral experiments, mice were 2-4 months old at the start of nicotine treatment. Mice were weaned at P21 and same-sex littermates were housed in cages with a maximum of five mice per cage. All mice were housed under a $12 \mathrm{~h}$ light/dark cycle with ad libitum access to food and water. All procedures received preapproval from the Baylor College of Medicine Institutional Animal Care and Use Committee and were performed in accordance with the guidelines for animal intramural research from the National Institutes of Health.

Brain slice preparation. Mice were anesthetized by intraperitoneal injection of a drug mixture containing the following (in $\mathrm{mg} / \mathrm{kg}$ ): 100 ketamine, 20 xylazine, and 3 acepromazine. After decapitation, brains were dissected and immediately placed into ice-cold cutting solution containing the following (in $\mathrm{mM}$ ): $125 \mathrm{NaCl}, 2.5 \mathrm{KCl}, 25 \mathrm{NaHCO}_{3}, 1.25$ $\mathrm{NaH}_{2} \mathrm{PO}_{4}, 25$ D-glucose, $4 \mathrm{MgCl}_{2}$, and $1 \mathrm{CaCl}_{2}$ bubbled with $95 \% \mathrm{O}_{2} / 5 \%$ $\mathrm{CO}_{2}$. Coronal brain slices containing the $\mathrm{MHb}$ were prepared in the same ice-cold cutting solution using a microtome (VT1000S; Leica Microsystems) at a thickness of $250 \mu \mathrm{m}$. After slicing, brain slices were transferred to an incubation chamber containing cutting solution, where they were kept at $32^{\circ} \mathrm{C}$ for $20 \mathrm{~min}$ and then at room temperature for at least $40 \mathrm{~min}$ until transfer to the recording chamber.

Electrophysiology. Slices were transferred to a recording chamber in an upright light microscope (Axioskop 2 FS; Carl Zeiss) and were continually bathed $(1-2 \mathrm{ml} / \mathrm{min}$ ) in recording solution (same as cutting solution with the following modifications: $1 \mathrm{mM} \mathrm{MgCl} 2,2 \mathrm{mM} \mathrm{CaCl}_{2}$ ) maintained at $32-34^{\circ} \mathrm{C}$ using a temperature controller (TC-324B; Warner Instruments). Whole-cell patch-clamp recordings were obtained from neurons in the $\mathrm{MHb}$ under visual guidance using borosilicate glass pipette electrodes. Electrodes were filled with a K-methanesulfonate-based internal solution containing the following (in mM): $130 \mathrm{CH}_{3} \mathrm{KO}_{3} \mathrm{~S}, 0.1$ EGTA, 10 HEPES, $2 \mathrm{MgCl} 2,4 \mathrm{Mg}$-ATP, 0.3 Tris-GTP, and 7 phosphocreatine ${ }^{\star}$ di(Tris), pH: 7.3, 280-285 mOsm.

Electrophysiological signals were acquired using a patch-clamp amplifer (Axoclamp 200B; Molecular Devices) and digitizer (Digidata 1322A; Molecular Devices) and recorded using pCLAMP (Molecular Devices). For current-clamp recordings, signals were filtered at $10 \mathrm{kHz}$ and sampled at $25 \mathrm{kHz}$. In voltage-clamp recording mode, signals were filtered at $5 \mathrm{kHz}$ and sampled at $20 \mathrm{kHz}$. Series resistance was monitored in voltage clamp using a series of three hyperpolarizing voltage steps $(-80$ to $-100 \mathrm{mV}, \Delta V=10 \mathrm{mV}$ ) from a $-70 \mathrm{mV}$ holding potential. For current-clamp experiments, a holding current was injected through the pipette to maintain a resting potential of $-70 \mathrm{mV}$. After drug application, the holding current was adjusted to preserve the $-70 \mathrm{mV}$ resting potential. Input resistance $\left(R_{\text {in }}\right)$ was measured using a series of hyperpolarizing current steps ( -10 to $-40 \mathrm{pA}, \Delta I=10 \mathrm{pA})$ and calculating $R_{\mathrm{in}}$ from Ohm's law $(V=I R)$. Intrinsic excitability was measured in current- clamp mode by injecting a series of 52 -s-long depolarizing current steps ( +10 to $+50 \mathrm{pA}, \Delta I=10 \mathrm{pA})$ at a frequency of $0.1 \mathrm{~Hz}$ and counting the number of resultant action potentials during each step. After baseline recordings, further recordings were performed after $10 \mathrm{~min}$ wash-in periods in which nicotine, substance $\mathrm{P}(\mathrm{SP})$, or neurokinin $\mathrm{B}(\mathrm{NKB})$ were added to the recording solution. In some experiments, slices were preincubated for at least $10 \mathrm{~min}$ with antagonists for nAChRs (mecamylamine or methyllycaconitine) or neurokinin receptors (L-732138, L-733060, or SB222200) before obtaining baseline recordings. Control recordings performed alongside experiments using agonists and antagonists resembled data from Figure 1 and were pooled together during the analysis. All drugs were purchased from either Sigma-Aldrich or Tocris Bioscience/ R\&D Systems.

Chronic nicotine treatment for electrophysiology. For experiments involving chronic nicotine treatment in animals destined for use in electrophysiology experiments, nicotine was delivered to experimental animals via the mothers' milk. Between $\mathrm{P} 1$ and $\mathrm{P} 3$, the male in a breeding cage was removed and the nursing dam was implanted with a $28 \mathrm{~d}$ osmotic minipump (Alzet) to deliver vehicle or nicotine (free base) at a constant rate of $8.4 \mathrm{mg} / \mathrm{kg} / \mathrm{d}$. To verify receipt of nicotine in the pups, blood serum was collected and analyzed for cotinine, a metabolite of nicotine, using an ELISA kit (Calbiotech). After brain slice preparation, slices were incubated in nicotine-free ACSF and used as usual for electrophysiology experiments.

Chronic nicotine treatment, habenula cannulation, and somatic nicotine withdrawal behaviors. Adult C57BL/6J mice were implanted on day 0 with osmotic minipumps (Alzet) to deliver saline alone or nicotine in saline at a constant rate of $8.4 \mathrm{mg} / \mathrm{kg} / \mathrm{d}$ (concentration expressed as free base). On days 9-10 of nicotine treatment, animals were implanted with bilateral cannulae into the $\mathrm{MHb}$ or LHb. These cannulae would be used during behavioral testing to deliver antagonists for neurokinin receptors. Behavioral testing began on day 12 and took place over the course of $3 \mathrm{~d}$. On day 1 of testing, $0.5 \mu$ l of either L-732138 (50 nM) in saline or saline alone was microinjected through the cannulae at a rate of $0.25 \mu \mathrm{l} / \mathrm{min}$. Mice were returned to their home cages and $10 \mathrm{~min}$ later were examined for the emergence of somatic withdrawal signs. The total number of cage scratches, wet dog shakes, grooming events, chewing motions, head noddings, and jumps during a 20 min examination period was noted and the cumulative sum of all these events became the score for the nicotine withdrawal assay (Salas et al., 2004a). On day 2 of testing, $0.5 \mu \mathrm{l}$ of SB222200 (100 nM) in saline was microinjected through the cannulae in animals that had previously received saline microinjections on testing day 1 and $0.5 \mu \mathrm{l}$ of saline was microinjected through the cannulae in the L-732138-treated animals. Upon return to the home cage, behavioral testing occurred as on day 12 . Finally, on testing day 3, animals either received $0.5 \mu \mathrm{l}$ microinjections of both L-732138 (50 nM) and SB222200 $(100 \mathrm{nM})$ in saline or saline alone and somatic withdrawal signs were assayed for a third time. After the completion of behavioral assays, histology was performed to confirm cannula placement.

Data analysis. All data were analyzed using Microsoft Excel and Statistica (Statsoft) software. For analyses of firing rate in response to depolarizing current steps, two-way ANOVA was used; asterisks in the figures indicate significance levels derived from the main effect of treatment (nicotine or neurokinins). Paired $t$ tests were used to compare $R_{\text {in }}$. Oneway ANOVA was used to compare nicotine-induced currents. In behavioral experiments, two-way ANOVA was used. For the comparison between nicotine-induced currents (see Fig. $3 B$ ) and for the withdrawal behavior studies (see Fig. 6), the Newman-Keuls post hoc test was used to further compare the groups. F-statistics and degrees of freedom displayed are of the main effect of nicotine.

\section{Results}

\section{Nicotine enhances the intrinsic excitability of MHb neurons}

We conducted patch-clamp experiments on neurons within the ventral two-thirds of the MHb because these comprise the cholinergic and cholinoceptive subdivisions of the nucleus (Fig. 1A; Arvidsson et al., 1997; Quick et al., 1999; Schütz et al., 2003; Lein et al., 2007). We first tested whether acutely applied nicotine 
A
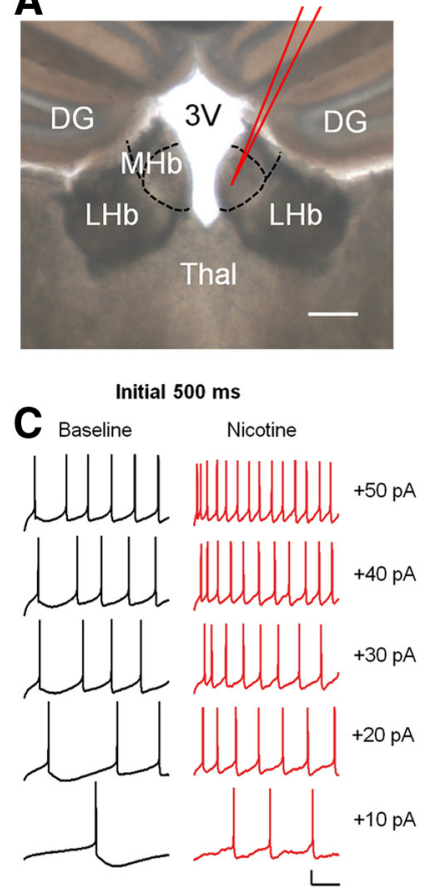

H

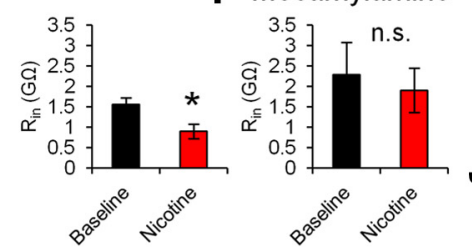

L Methyllycaconitine

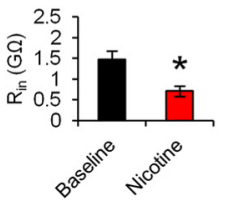

B

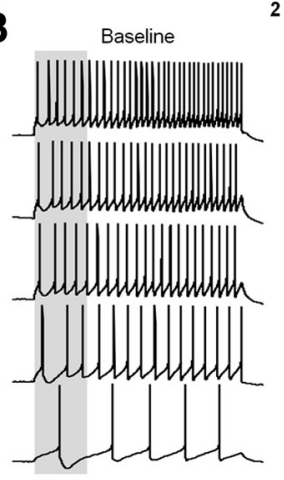

D

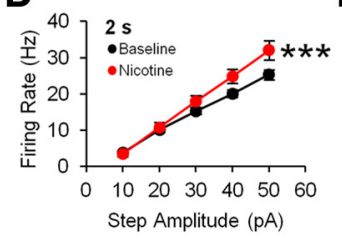

F Mecamylamine
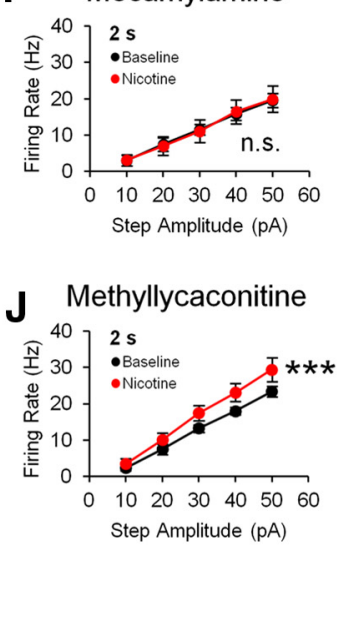

$2 \mathrm{~s}$

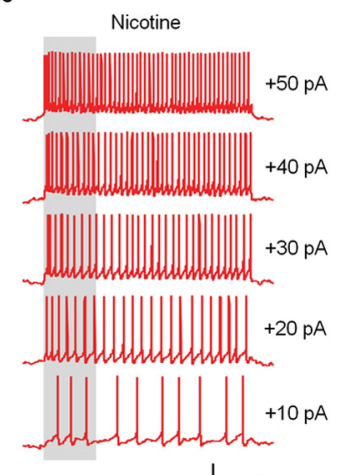

E

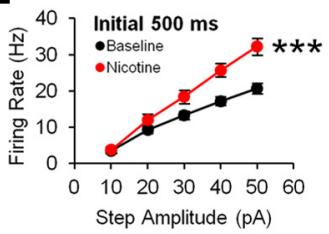

G Mecamylamine
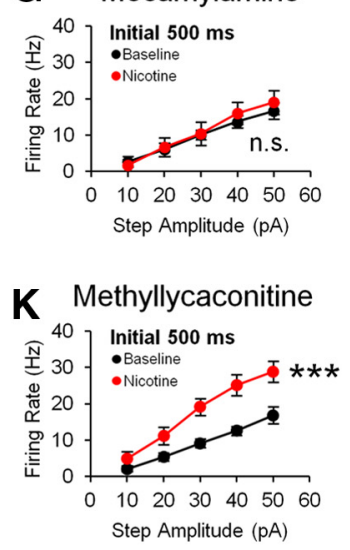

Figure 1. Nicotine enhances the intrinsic excitability of $\mathrm{MHb}$ neurons. $\boldsymbol{A}$, For all electrophysiological experiments, neurons were used from the cholinoceptive and cholinergic ventral two-thirds (red pipette) of the medial habenula (dashed lines) in coronal brain slices. MHb neurons were held at $-70 \mathrm{mV}$ in current-clamp configuration and subjected to 2 s depolarizing current steps of increasing amplitudes ( $10-50 \mathrm{pA}, \Delta \mathrm{I}=10 \mathrm{pA})$ to elicit action potentials. After nicotine (1 $\mu \mathrm{M})$ bath application, the holding current was readjusted to maintain the $-70 \mathrm{mV}$ resting potential and the protocol was repeated. $\boldsymbol{B}$, Example traces show that, after nicotine bath application, the number of action potentials elicited by each current step increased over the corresponding response during baseline, indicating that an increase in intrinsic excitability had occurred. C, Facilitation of firing by nicotine was especially evident during the initial $500 \mathrm{~ms}$ of the current steps. Displayed traces in C are enlarged from the portion of the traces in $\boldsymbol{B}$ within the gray boxes. D, $\boldsymbol{E}$, Quantified firing responses to the current steps for the entire $2 \mathrm{~s}$ step $(\boldsymbol{D})$ or the initial $500 \mathrm{~ms}(\boldsymbol{E})$ reflect the nicotine-induced enhancement of excitability ( $n=20$ cells $/ 14$ mice). $\boldsymbol{F}, \mathbf{G}$, Blockade of heteromeric $n A C h R s$ by mecamylamine $(10 \mu \mathrm{m})$ preincubation blocked the enhancement of excitability by subsequent application of nicotine $(1 \mu \mathrm{m} ; n=6$ cells $/ 3$ mice). $\boldsymbol{H}, \boldsymbol{I}$, Nicotine bath application caused a reduction in $R_{\text {in }}$ ( $n=20$ cells $/ 12$ mice), which was blocked by preincubation with mecamylamine ( $n=6$ cells $/ 3$ mice). $\boldsymbol{J}, \boldsymbol{K}$, Preincubation with methyllycaconitine $(5 \mathrm{~nm}$ ) did not alter the facilitation of intrinsic excitability by subsequent nicotine application ( $n=7$ cells $/ 5$ mice). $L$, Likewise, it did not prevent the decrease in $R_{\text {in }}$ by nicotine ( $n=7$ cells $/ 5$ mice). Scale bars: $\boldsymbol{A}, 200 \mu \mathrm{m} ; \boldsymbol{B}, 20 \mathrm{mV} / 500 \mathrm{~ms} ; \boldsymbol{C}, 20 \mathrm{mV} / 100 \mathrm{~ms}$. All values are displayed as mean \pm SEM. ${ }^{*} p<$ $0.05 ;{ }^{* * *} p<0.001$. Thal, thalamus; $3 \mathrm{~V}$, third ventricle; $D G$, dentate gyrus.

modulates the intrinsic excitability of MHb neurons by subjecting $\mathrm{MHb}$ neurons in current-clamp configuration to current steps of increasing amplitude (10-50 pA) starting from a holding potential of $-70 \mathrm{mV}$. Because $\mathrm{MHb}$ neurons fire action potentials spontaneously (McCormick and Prince, 1987), negative current was generally required to maintain the desired resting membrane potential. We compared the action potential firing of
$\mathrm{MHb}$ neurons to depolarizing current steps (2s) before and after bath application of nicotine $(1 \mu \mathrm{M}$; Fig. $1 B, D)$. In the presence of nicotine, the holding current was increased to maintain the cell at the same resting potential of $-70 \mathrm{mV}$. After nicotine application, despite maintaining the resting potential, a greater number of action potentials was elicited during each depolarizing current step $(n=20$ cells $/ 14$ mice, $\left.F_{(1,95)}=34.60, p<0.001\right)$. The increase in firing was particularly prominent during the initial portion of the current steps $\left(n=20\right.$ cells $/ 4$ mice, $F_{(1,95)}=$ 94.46, $p<0.001)$. Although the average firing rate across the $2 \mathrm{~s}$ step increased by up to $\sim 25 \%$ over baseline, the average firing rate during the initial $500 \mathrm{~ms}$ of each step increased by up to $~ 55 \%$ over baseline (Fig. 1C,E). Similar results were obtained using nicotine at $100 \mathrm{~nm}$ (data not shown). Preincubation with the $\mathrm{nACh}$ antagonist mecamylamine (10 $\mu \mathrm{M}$; Papke et al., 2008) blocked the facilitation of intrinsic excitability during nicotine $(1 \mu \mathrm{M})$ application $(n=6$ cells $/ 3$ mice, $p>0.05$; Fig. $1 F, G)$. In contrast, when slices were preincubated with the $\mathrm{nAChR}$ antagonist methyllycaconitine (5 nM), which preferentially inhibits $\alpha 7$ homomeric nAChRs (Alkondon et al., 1992; Palma et al., 1996; $\mathrm{Yu}$ and Role, 1998), the facilitation of intrinsic excitability by nicotine remained across both the entire $2 \mathrm{~s}$ step $(n=7$ cells $/ 5$ mice, $\left.F_{(1,30)}=16.92, p<0.001\right)$ and within the initial $500 \mathrm{~ms}$ of each step $\left(n=7\right.$ cells $/ 5$ mice, $F_{(1,30)}=59.95, p<$ 0.001 ; Fig. $1 \mathrm{~J}, K)$. Therefore, heteromeric nAChRs, which are sensitive to blockade by mecamylamine, likely underlie the facilitative effect of nicotine on intrinsic excitability.

\section{Nicotine decreases the input resistance of neurons in the $\mathrm{MHb}$}

An increase in $R_{\text {in }}$ could explain the augmented intrinsic excitability upon nicotine application: with increased $R_{\text {in }}$, neurons would respond more to the same depolarizing current steps with greater voltage deflections and a consequent increase in action potential firing. However, when we measured $R_{\text {in }}$ before and after nicotine $(1 \mu \mathrm{M})$ application, we found that it dramatically decreased in the presence of nicotine (baseline: $1.76 \pm 0.24 \mathrm{G} \Omega$ vs nicotine: $0.92 \pm 0.27 \mathrm{G} \Omega, n=20$ cells $/ 12$ mice, $p<0.05$; Fig. $1 H$ ), which is consistent with the opening of nAChRs. This decrease was abolished by preincubation with mecamylamine (baseline: $2.28 \pm 0.79 \mathrm{G} \Omega$ vs nicotine: $1.90 \pm 0.54 \mathrm{G} \Omega, n=6$ cells $/ 3$ mice, $p>0.05)$, but not by preincubation with methyllycaconitine (baseline: $1.47 \pm 0.20$ $\mathrm{G} \Omega$ vs nicotine: $0.72 \pm 0.13 \mathrm{G} \Omega, n=7$ cells $/ 5$ mice, $p<0.05$; 
Fig. 1I,L). Therefore, an increase in $R_{\text {in }}$ is not the mechanism through which nicotine acts to promote intrinsic excitability.

\section{$\alpha 5 \mathrm{nAChR}$ subunit is required for nicotine-induced increase in excitability}

The $\mathrm{MHb}$ expresses a large complement $(\alpha 3-7, \beta 2-4)$ of $\mathrm{nAChR}$ subunits (Sheffield et al., 2000). To determine the nAChR subunits necessary for nicotine's facilitation of excitability, we used mice with null mutations in targeted $\mathrm{nAChR}$ subunits. Genetic variants in the CHRNA5/ CHRNA3/CHRNB4 gene cluster, which encodes the $\alpha 5, \alpha 3$, and $\beta 4 \mathrm{nAChR}$ subunits (Duga et al., 2001), were found in genomic studies to influence various aspects of nicotine addiction (Saccone et al., 2007; Bierut et al., 2008; Thorgeirsson et al., 2008). Expressed in habenular nAChRs, these subunits are important for the aversive aspects of nicotine dependence (Salas et al., 2004a; Salas et al., 2009; Fowler et al., 2011; Frahm et al., 2011). Motivated by these genomic and behavioral studies, we focused our investigation on these $\mathrm{nAChR}$ subunits, particularly the $\alpha 5$ and $\beta 4$ subunits, because of their demonstrated roles in aversive nicotine-related behaviors. Mice null for the $\alpha 3$ subunit were not examined because they have impaired growth and predominantly die before postnatal week 2 (Xu et al., 1999). In mice null for the $\alpha 5$ subunit, the nicotine-induced $(1 \mu \mathrm{M})$ facilitation of excitability observed in wild-type mice was abolished $(n=10$ cells $/ 8$ mice, $p>$ 0.05; Fig. $2 A, D, G)$. Nevertheless, in the initial $500 \mathrm{~ms}$ of the step response, an attenuated nonsignificant trend toward facilitation remained at the highest amplitude tested (Fig. 2D,G). Conversely, in mice null for the $\beta 4$ subunit, the facilitation of excitability by nicotine remained for both the entire $2 \mathrm{~s}$ step $(n=8$ cells $/ 7$ mice, $F_{(1,35)}=64.15, p<0.001$; Fig. $\left.2 B\right)$ and the initial $500 \mathrm{~ms}(n=8$ cells/7 mice, $F_{(1,35)}=108.47, p<0.001$; Fig. $\left.2 E, H\right)$. Interestingly, although the $R_{\text {in }}$ decreased after nicotine application in $\alpha 5$-null mice (baseline: $2.22 \pm 0.40 \mathrm{G} \Omega$ vs nicotine: $0.59 \pm 0.14 \mathrm{G} \Omega, n=12$ cells $/ 7$ mice, $p<0.01$; Fig. $2 J)$, the corresponding effect was abolished in $\beta 4$-null mice (baseline: $1.84 \pm 0.41 \mathrm{G} \Omega$ vs nicotine: $1.04 \pm 0.42 \mathrm{G} \Omega, n=9$ cells $/ 5$ mice, $p>0.05$; Fig. $2 K)$.

Since $\alpha 5$-containing $\left(\alpha 5^{*}\right) \mathrm{nAChRs}$ are heteropentamers containing at least one $\beta$ subunit (Couturier et al., 1990) and the $\beta 4$-null mutation did not affect nicotine's enhancement of excitability, we investigated whether the $\beta 2$ subunit, also expressed in the MHb (Sheffield et al., 2000), is necessary for nicotine's effect on excitability. In $\beta 2$-null mice, the effect of nicotine $(1 \mu \mathrm{M})$ on the step-evoked firing response was abol-

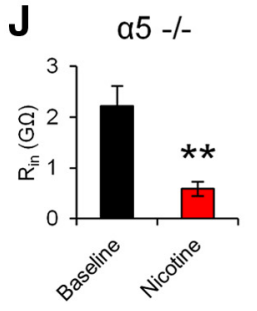

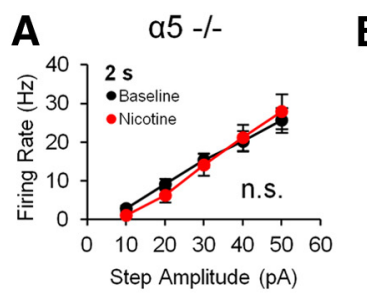
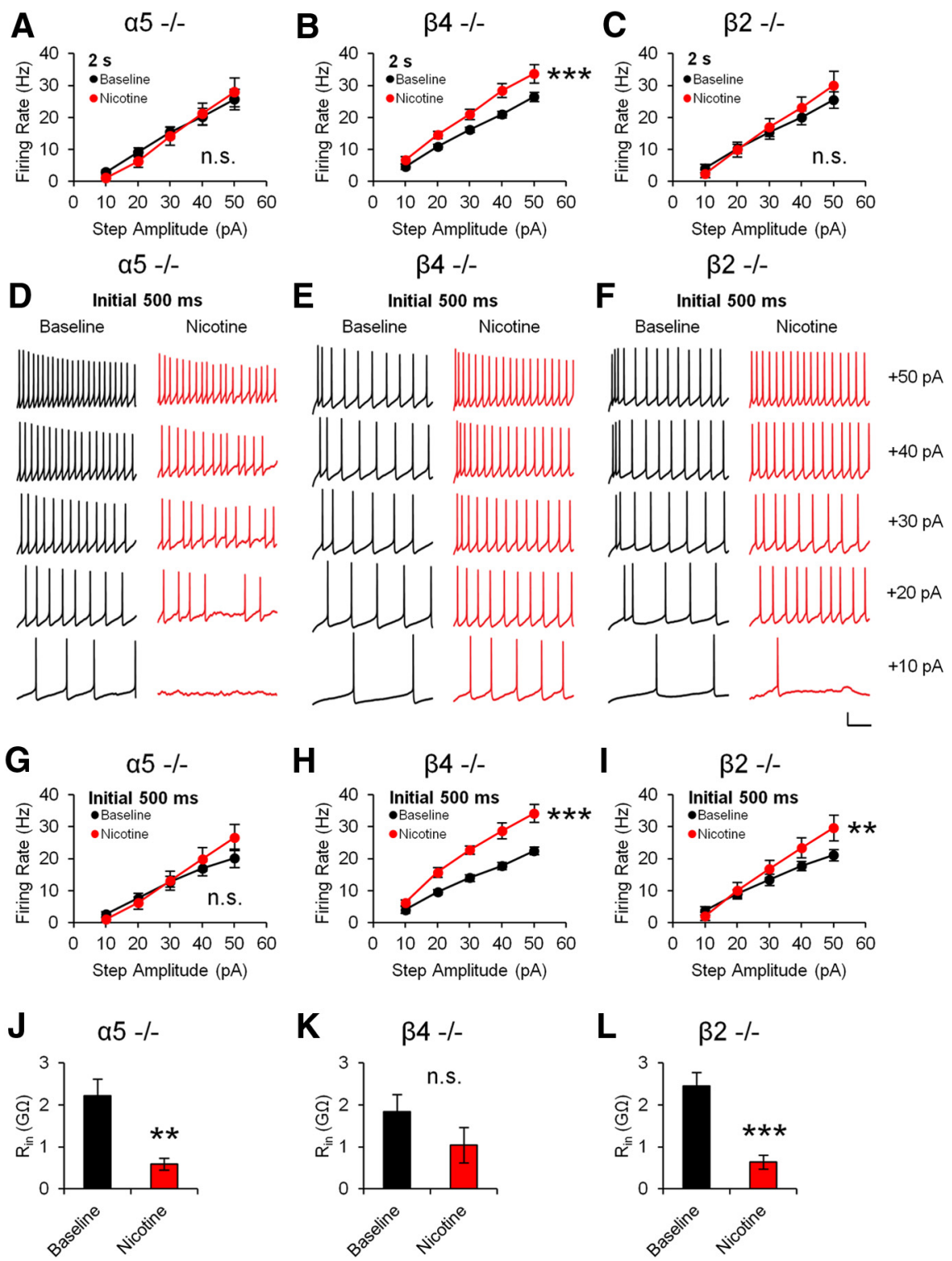

Figure 2. Null mutation of the $\alpha 5 \mathrm{nAChR}$ subunit blocks facilitation of excitability. Mice mutant for various $\mathrm{nAChR}$ subunits were used to address the subunit composition of the nAChRs that underlie nicotine's enhancement of excitability. We initially focused on two subunits encoded for in the CHRNA5/CHRNA3/CHRNB4 gene cluster, $\alpha 5$ and $\beta 4 . \boldsymbol{A}, \boldsymbol{D}, \mathbf{G}$, Null mutation of the $\alpha 5$ subunit abolished the increase in intrinsic excitability after nicotine $(1 \mu \mathrm{m})$ bath application ( $n=10$ cells $/ 8$ mice). This blockade of nicotine's effect was observed both across the entire 2 s step $(\boldsymbol{A})$, as well as during the initial $500 \mathrm{~ms}(\boldsymbol{D}, \boldsymbol{G}) . \boldsymbol{B}, \boldsymbol{E}, \boldsymbol{H}$, Conversely, the facilitative effect of nicotine persisted in mice bearing a $\beta 4$ subunit null mutation ( $n=8$ cells $/ 7$ mice). $C, F, I$, We also analyzed the $\beta 2$ subunit and observed an intermediate effect in mice bearing a $\beta 2$-null mutation. The facilitative effect of nicotine on intrinsic excitability was blocked when averaging across the entire $2 \mathrm{~s}$ step duration, but persisted during of the initial $500 \mathrm{~ms}(n=7$ cells $/ 5$ mice). $\boldsymbol{J}-\boldsymbol{L}$, Null mutation of the $\beta 4$ subunit $(\boldsymbol{K})$ blocked the nicotine-induced decrease in $R_{\text {in }}$ ( $n=9$ cells $/ 5$ mice), whereas null mutations in the $\alpha 5(\boldsymbol{J})$ or $\beta 2(\boldsymbol{L})$ subunits did not ( $n=12$ cells $/ 7$ mice, 12 cells $/ 5$ mice). Scale bar indicates $20 \mathrm{mV} / 100 \mathrm{~ms}$. All values are displayed as mean \pm SEM. ${ }^{* *} p<0.01 ;{ }^{* * *} p<0.001$.

ished when averaged across the entire $2 \mathrm{~s}$ step ( $n=7$ cells $/ 5$ mice, $p>0.05$; Fig. $2 C$ ), whereas the increase in the response during the initial $500 \mathrm{~ms}$ of the step remained $(n=7$ cells $/ 5$ mice, $F_{(1,30)}=8.24, p<0.01$; Fig. $\left.2 F, I\right)$. Furthermore, the $R_{\text {in }}$ decrease after nicotine application was preserved in $\beta 2$-null mice (baseline: $2.46 \pm 0.32 \mathrm{G} \Omega$ vs nicotine: $0.64 \pm 0.16 \mathrm{G} \Omega$, $n=12$ cells $/ 5$ mice, $p<0.001$; Fig. $2 L$ ). Together, these results suggest that nicotine enhances intrinsic excitability by acting at $\mathrm{nAChRs}$ that contain the $\alpha 5$ and $\beta 2$ subunits.

To determine whether the abolishment of nicotine's effect on intrinsic excitability by the $\alpha 5$-null mutation was due to a reduc- 

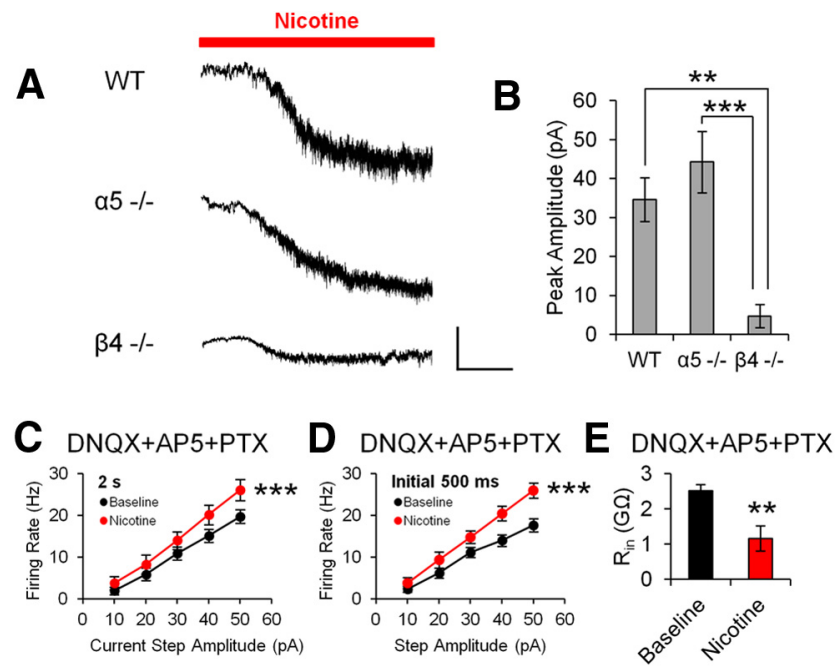

Figure 3. Enhancement of excitability by nicotine does not require postsynaptic $n A C h R$ function, ionotropic glutamatergic transmission, or GABAergic transmission. Nicotinic currents were measured in MHb neurons from WT, $\alpha 5$-null, and $\beta 4$-null mice by bath application of nicotine $(1 \mu \mathrm{M})$ at a holding voltage of $-70 \mathrm{mV}$. $\boldsymbol{A}$, Representative traces illustrate that, although the $\alpha 5$-null mutation had no effect on the peak current (middle), the $\beta 4$-null mutation greatly reduced it (bottom). Nicotine bath application (red bar) began at the start of the trace and perfused steadily into the experimental chamber. $\boldsymbol{B}$, Quantification of peak currents elicited by nicotine $(1 \mu \mathrm{m})$ indicated that only $13.6 \%$ of the WT nicotinic current remained in the $\beta 4$-null mouse ( $n=9$ cells $/ 5$ mice, 8 cells $/ 6$ mice, and 8 cells $/ 3$ mice, for WT, $\alpha 5^{-1-}$, and $\beta 4^{-1-}$, respectively). $\boldsymbol{C}-\boldsymbol{E}$, Blockade of ionotropic glutamate and $\mathrm{GABA}$ receptors by preincubation with DNQX $(10 \mu \mathrm{M}) / \mathrm{AP5}(50 \mu \mathrm{m}) /$ picrotoxin $(100 \mu \mathrm{M})$ did not block the enhancement of excitability produced by nicotine ( $1 \mu \mathrm{m} ; n=12$ cells/9 mice), nor did it affect the nicotine-induced decrease in $R_{\text {in }}(n=7$ cells $/ 2$ mice; $\boldsymbol{E})$. Scale bar indicates $20 \mathrm{pA} / 4 \mathrm{~min}$. All values are displayed as mean \pm SEM. ${ }^{* *} p<0.01 ;{ }^{* * *} p<0.001$.

tion in overall nAChR function, we measured current responses evoked by $1 \mu \mathrm{M}$ nicotine in $\mathrm{MHb}$ neurons under voltage clamp (Fig. $3 A, B$ ). Despite the abolishment of nicotine's enhancement of intrinsic excitability in $\alpha 5$-null mice, we found that evoked currents in $\alpha 5$-null mice were similar to those of WT mice (WT: $34.7 \pm 5.6 \mathrm{pA}$ vs $\alpha 5-/-: 44.3 \pm 7.8 \mathrm{pA} ; n=9$ cells $/ 5$ mice, $n=$ 8 cells/ 6 mice). However, when we analyzed the $\beta 4$-null mice, nicotine-evoked currents were severely diminished $(4.7 \pm 3.0$ $\mathrm{pA}, n=8$ cells $/ 3$ mice; ANOVA: $F_{(2,22)}=12.15, p<0.001$; Newman-Keuls: $p<0.01$ vs WT, $p<0.001$ vs $\alpha 5$ ) and often there were failures to produce any current at all. This finding suggests that the $\beta 4 \mathrm{nAChR}$ subunit is essential to the proper function of postsynaptic nAChRs. Moreover, because the decrease in $R_{\text {in }}$ after nicotine application was abolished in $\beta 4$-null mice, the direct activation of postsynaptic $\beta 4^{\star} \mathrm{nAChRs}$ is likely responsible for the reduction of $R_{\text {in }}$ observed after nicotine application (Fig. $1 H$ ).

The observation that postsynaptic nicotinic currents were not appropriately correlated with the nicotine-induced enhancement of excitability suggested the involvement of presynaptic mechanisms. The $\mathrm{MHb}$ receives substantial glutamatergic and GABAergic innervation from the medial septum/diagonal band and nucleus triangularis, respectively (Qin and Luo, 2009). To test the possibility that glutamatergic or GABAergic mechanisms were involved in nicotine's enhancement of excitability, we preincubated brain slices in a mixture of ionotropic glutamate and GABA receptor antagonists ( $10 \mu \mathrm{M}$ DNQX, $50 \mu \mathrm{M}$ AP5, $100 \mu \mathrm{M}$ picrotoxin) to block neurotransmission through those receptors. Using current steps to test excitability, we found that the enhancement of excitability by nicotine $(1 \mu \mathrm{M})$ persisted in this configuration ( 2 s step: $n=12$ cells $/ 9$ mice, $F_{(1,55)}=57.00, p<$
0.001; initial 500 ms: $n=12$ cells $/ 9$ mice, $F_{(1,55)}=102.52, p<$ 0.001 ; Fig. $3 C, D)$, leading to the hypothesis that the $\alpha 5^{\star} \mathrm{nAChRs}$ that mediated this effect are not positioned presynaptically on glutamategic or GABAergic afferents. This antagonist combination also did not block the decrease in $R_{\text {in }}$ due to nicotine (baseline: $2.52 \pm 0.17 \mathrm{G} \Omega$ vs nicotine: $1.16 \pm 0.36 \mathrm{G} \Omega, n=7$ cells $/ 2$ mice, $p<0.01$; Fig. $3 E$ ), which is consistent with our hypothesis that the decrease in $R_{\text {in }}$ is due to direct activation of postsynaptic $\beta 4^{\star}$ nAChRs.

\section{Neurokinins participate in the nicotine-induced enhancement of excitability in the $\mathrm{MHb}$}

In addition to glutamate, GABA, and acetylcholine, an array of other neurotransmitters and neuromodulators are expressed in the $\mathrm{MHb}$, including norepinephrine (Gottesfeld, 1983), serotonin (Kinsey et al., 2001), ATP (Edwards et al., 1992), and numerous neuropeptides (Burgunder and Young, 1989; Langlois et al., 2001; Kopp et al., 2002). Because neurokinins can have effects on intrinsic excitability that are similar to those produced by nicotine on MHb neurons (Sculptoreanu and de Groat, 2007; Copel et al., 2009; Xia et al., 2010), we investigated whether an interaction with the neurokinin signaling system mediates nicotine's effects on intrinsic excitability. We initially tested whether blockade of the NK1 or NK3 receptors would reduce the facilitation of excitability by nicotine $(1 \mu \mathrm{M})$ in $\mathrm{MHb}$ neurons. Using L-732138 (10 $\mu \mathrm{M}$; Cascieri et al., 1994) and SB222200 (2 $\mu \mathrm{M}$; Goldhill and Angel, 1998; Sarau et al., 2000) to block NK1 and NK3 receptors, respectively, we found that both antagonists separately abolished nicotine's enhancement of excitability when averaged across the entire $2 \mathrm{~s}$ test step (L-732138: $n=8$ cells $/ 6$ mice, $p>0.05$; SB222200: $n=5$ cells $/ 5$ mice, $p>0.05$; Fig. $4 A, B)$. L-733060 ( $3 \mu \mathrm{M})$, another antagonist of NK1 receptors, was also tested and had similar effects (data not shown). Interestingly, for any neurokinin receptor antagonist used alone, the nicotineinduced enhancement of excitability during the initial $500 \mathrm{~ms}$ of steps was reduced but not completely abolished (L-732138: $n=8$ cells $/ 6$ mice, $F_{(1,35)}=4.68, p<0.05$; SB222200: $n=5$ cells $/ 5$ mice, $F_{(1,20)}=8.89, p<0.01$; Fig. $\left.4 D, E, G, H\right)$. However, when both L-732138 (NK1) and SB222200 (NK3) were applied together, nicotine's enhancement of excitability was completely suppressed during the initial $500 \mathrm{~ms}$ window $(n=7$ cells $/ 4$ mice, $p>0.05$; Fig. $4 F, I)$ and when averaged over the full $2 \mathrm{~s}$ step $(n=$ 7 cells $/ 4$ mice, $p>0.05$; Fig. $4 C$ ). The nicotine-induced decrease in $R_{\text {in }}$ was unaffected by preincubation with any neurokinin receptor antagonist (L-732138: baseline: $1.65 \pm 0.27 \mathrm{G} \Omega$ vs nicotine: $0.61 \pm 0.29 \mathrm{G} \Omega, n=9$ cells $/ 6$ mice, $p<0.01$; SB222200: baseline: $2.12 \pm 0.31 \mathrm{G} \Omega$ vs nicotine: $0.66 \pm 0.28 \mathrm{G} \Omega, n=8$ cells/5 mice; $p<0.01$; L-732138 + SB222200: baseline: $1.73 \pm$ $0.31 \mathrm{G} \Omega$ vs nicotine: $0.60 \pm 0.27 \mathrm{G} \Omega, n=7$ cells $/ 4$ mice; $p<0.05$; Fig. $4 J-L)$.

SP and NKB are endogenous NK1 and NK3 receptor agonists, respectively, that are present in the $\mathrm{MHb}$ (Lein et al., 2007). Given the hypothesis that nicotine's enhancement of intrinsic excitability in the MHb is mediated through neurokinin release, we tested whether application of these endogenous ligands to $\mathrm{MHb}$ neurons mimics the observed effects of nicotine. Bath application of SP (100 nM) and NKB (100 nM) mimicked nicotine's facilitation of excitability, both when averaged across the entire $2 \mathrm{~s}$ duration of step currents (SP: $n=7$ cells/ 6 mice, $F_{(1,30)}=13.39, p<0.001$; $\mathrm{NKB}: n=11$ cells $/ 7$ mice, $\left.F_{(1,50)}=78.72, p<0.001\right)$ and during the initial $500 \mathrm{~ms}$ (SP: $n=7$ cells $/ 6$ mice, $F_{(1,40)}=113.50, p<$ 0.001 ; NKB: $n=11$ cells $/ 7$ mice, $F_{(1,50)}=108.22$, $p<0.001$; Fig. $5 A-F)$. Importantly, these agonists produced the observed effects 
without lowering $R_{\text {in }}$ (SP: baseline: $1.81 \pm$ $0.28 \mathrm{G} \Omega$ vs nicotine: $1.65 \pm 0.14 \mathrm{G} \Omega, n=$ 9 cells/ 5 mice, $p>0.05$; NKB: baseline: $2.33 \pm 0.22 \mathrm{G} \Omega$ vs nicotine: $1.73 \pm 0.22$ $\mathrm{G} \Omega, n=15$ cells $/ 7$ mice, $p>0.05$; Fig. $5 G, H)$. Together, these data indicate that the facilitation of $\mathrm{MHb}$ neuronal excitability by nicotine occurs via an indirect pathway in which the activation of $\alpha 5^{*}$ nAChRs promotes neurokinin signaling onto $\mathrm{MHb}$ neurons expressing NK1 and NK3 receptors.

\section{Microinjection of neurokinin receptor antagonists into the $\mathrm{MHb}$ precipitates withdrawal behaviors}

Because the emergence of somatic withdrawal behavior in mice chronically treated with nicotine critically depends on $\alpha 5^{*}$ nAChRs (Salas et al., 2009), we sought to determine whether the enhancement of $\mathrm{MHb}$ neuronal excitability through NK1 and NK3 receptor activation is a necessary component of the $\alpha 5^{*}$ nAChR-dependent nicotine withdrawal response. Using mice chronically treated with nicotine $(8.4 \mathrm{mg} /$ $\mathrm{kg} / \mathrm{d}$ ) via subcutaneous osmotic minipumps, we attempted to elicit nicotine withdrawal behavior by microinjection of NK1 and NK3 receptor antagonists directly into the MHb. Habenular microinjection of L-732138 (NK1) alone, SB222200 (NK3) alone, or both antagonists together each resulted in significantly increased numbers of somatic signs of nicotine withdrawal above vehiclemicroinjected controls (Fig. 6A, red bars, $n=19$ for vehicle, $n=7$ for each drugmicroinjected group, $F_{(3,56)}=9.95, p<$ $0.001)$. Interestingly, microinjections of SB222200 alone produced an elevated withdrawal score above that of L-732138 microinjections alone or microinjections of both drugs together. These effects were specific to the MHb because similar microinjections into the LHb of mice chronically treated with nicotine did not elicit elevated somatic signs (Fig. 6A, pink bars, $n=6$ for vehicle, $n=5$ for each drugmicroinjected group, $p>0.05)$. Furthermore, in another group of animals implanted with minipumps delivering a nicotine-free vehicle solution, analogous microinjections into the $\mathrm{MHb}$ also did not elicit elevated somatic signs (Fig. $6 A$, inset, yellow bars, $n=9$ for Vehicle, $n=5$ for each drug-microinjected group, $p>0.05$ ). In sum, these results directly implicate neurokinin signaling within the MHb in the emergence of nicotine withdrawal behavior.

\section{Chronic nicotine exposure reduces nicotine-induced enhancement of excitability}

To gain insight into potential consequences of chronic nicotine over acute nicotinic modulation of intrinsic excitability, we mon-

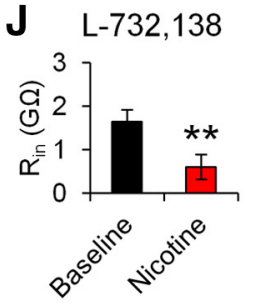

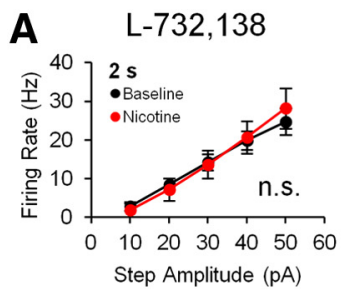

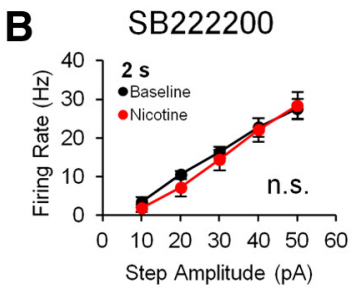

C L-732,138+SB222200
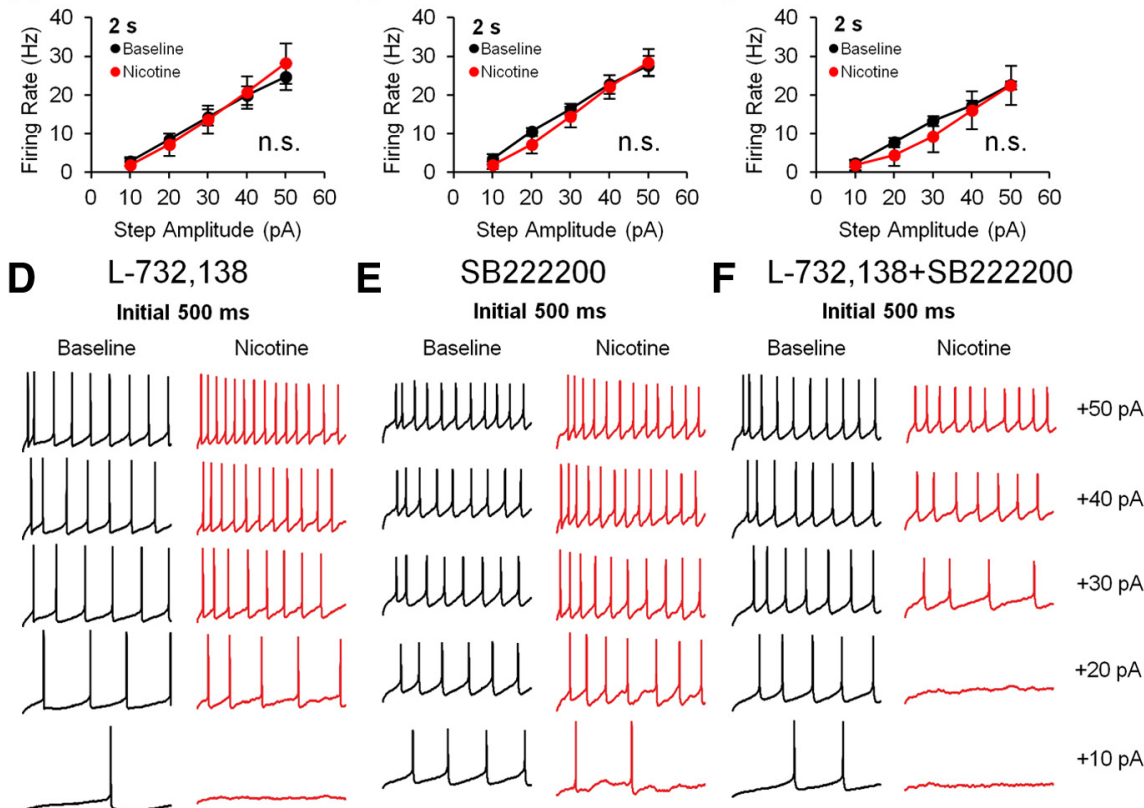

$+20 \mathrm{pA}$
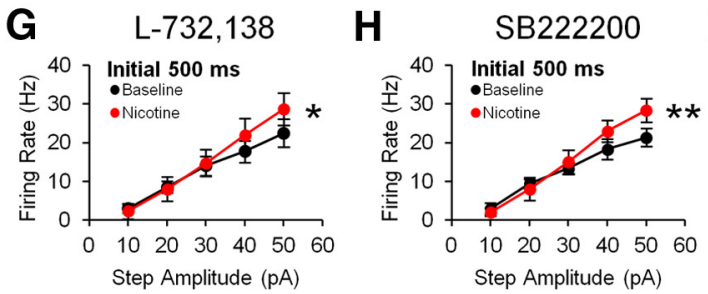

I L-732,138+SB222200
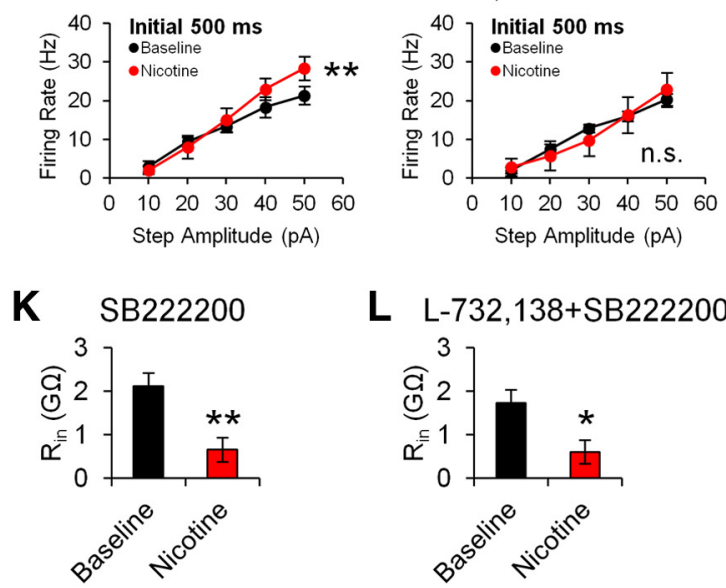

L $\quad$ L-732,138+SB222200

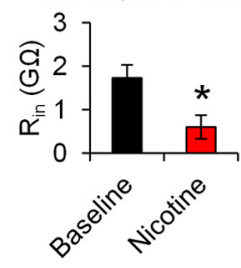

Figure 4. Neurokinin receptor antagonists block nicotine-induced facilitation of excitability. To investigate a potential interplay between the nicotinic and neurokinin signaling systems, we preincubated brain slices with antagonists for NK1 (L-732138) and NK3 (SB222200) receptors both separately and together before assaying for excitability. Preincubation with L-732138 (10 $\mu$ m; $\boldsymbol{A})$, SB222200 (2 $\mu \mathrm{M} ; \boldsymbol{B})$, or both antagonists simultaneously (C) blocked the nicotine-induced $(1 \mu \mathrm{m})$ increase in firing rate of action potentials evoked by 2 s current steps ( $n=8$ cells $/ 6$ mice, 5 cells $/ 5$ mice, and 7 cells $/ 4$ mice, for L-732138, SB222200, and both together, respectively). Conversely, we observed a slightly different outcome upon examination of the initial $500 \mathrm{~ms}$ of each step. With either L-732138 (D, G) or SB222200 $(\boldsymbol{E}, \boldsymbol{H})$ preincubation alone, the nicotine-induced increase in firing rate of elicited action potentials during the initial $500 \mathrm{~ms}$ of each step persisted ( $n=8$ cells $/ 6$ mice, 5 cells $/ 5$ mice, respectively). $\boldsymbol{F}, \boldsymbol{I}$, However, the combined preincubation of both antagonists together completely abolished nicotine's effect on excitability during the initial 500 ms of steps ( $n=7$ cells/4 mice), as it did for the entire $2 \mathrm{~s}$ step. $\boldsymbol{J}-\boldsymbol{L}$, Neurokinin receptor antagonists failed to block the nicotine-induced decrease in $R_{\text {in }}$ ( $n=9$ cells $/ 6$ mice, 8 cells $/ 5$ mice, and 7 cells $/ 4$ mice, for L-732138, SB222200, and both together, respectively). Scale bar indicates $20 \mathrm{mV} / 100 \mathrm{~ms}$. All values are displayed as mean $\pm \mathrm{SEM}$. ${ }^{*} p<0.05 ;{ }^{* *} p<0.01$.

itored MHb neuronal excitability in mice chronically treated with nicotine or vehicle solution. Because we used adolescent mice for electrophysiology experiments, we chose a chronic nicotine paradigm in which nursing mice obtained nicotine via the milk of their mothers, which had been implanted with osmotic minipumps to deliver nicotine $(8.4 \mathrm{mg} / \mathrm{kg} / \mathrm{d})$ or vehicle. Nicotine exposure was verified using an ELISA to detect the nicotine metabolite cotinine in the serum of mice. The serum concentration of cotinine was determined to be $16.3 \pm 2.6 \mathrm{ng} / \mathrm{ml}$ in the offspring of chronic nicotine-treated dams, whereas cotinine was 
A

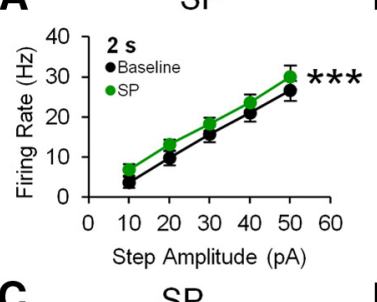

C

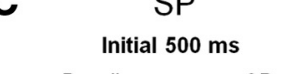

Baseline

SP

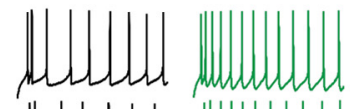

แ」」

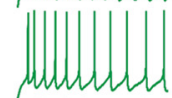

$\| \downarrow$

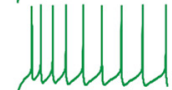

$1\rfloor$

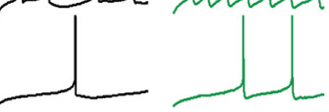

E

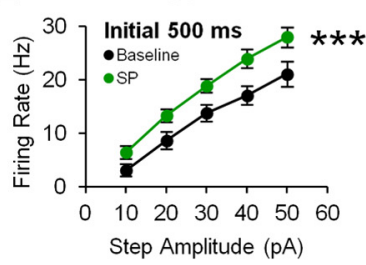

$\mathbf{F}$
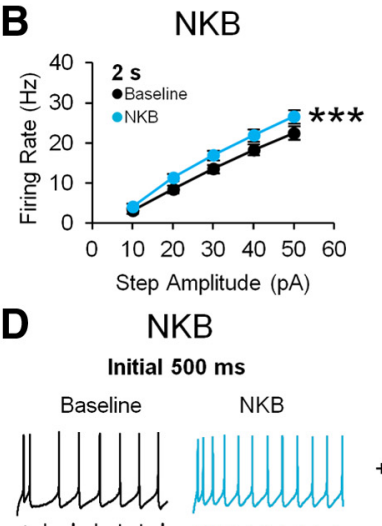

$+50 \mathrm{pA}$

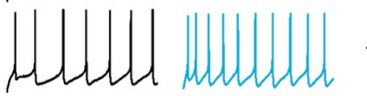

$+40 \mathrm{pA}$
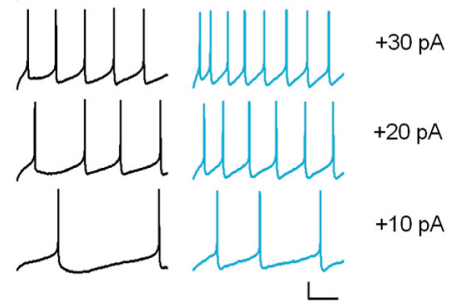

NKB
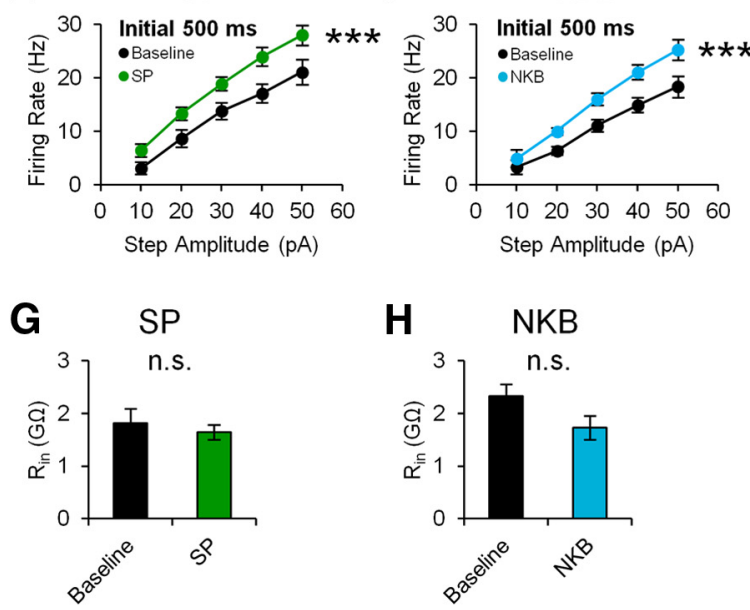

Figure 5. Neurokinins mimic nicotine-induced facilitation of excitability. To test whether nicotine's facilitation of intrinsic excitability could occur through promotion of neurokinin signaling, we used bath application of the neurokinins SP (100 nM) and NKB (100 nM) to mimic nicotine's effect. Bath application of either SP $(\boldsymbol{A})$ or NKB $(\boldsymbol{B})$ increased the firing of action potentials elicited by 2 s depolarizing current steps $(10-50 \mathrm{pA}, \Delta \mathrm{I}=10 \mathrm{pA} ; n=7$ cells $/ 6$ mice, 11 cells/7 mice, respectively). $\boldsymbol{C}-\boldsymbol{F}$, Examination of the initial $500 \mathrm{~ms}$ of the step revealed a similar and more pronounced outcome for both SP and NKB, compared with the increase across the entire $2 \mathrm{~s}$ step ( $n=7$ cells $/ 6$ mice, 11 cells $/ 7$ mice). $\boldsymbol{G}, \boldsymbol{H}$, Bath application of SP or NKB did not affect $R_{\text {in }}$ ( $n=9$ cells $/ 5$ mice, 15 cells $/ 7$ mice, respectively). Scale bar indicates $20 \mathrm{mV} / 100$ ms. All values are displayed as mean \pm SEM. ${ }^{* * *} p<0.001$.

undetectable in samples from vehicle-treated mice. In comparison, the serum cotinine concentration from the nicotine-treated dams was $>100 \mathrm{ng} / \mathrm{ml}$, the concentration of the highest cotinine standard in the assay.

Brain slices from vehicle-treated mice responded similarly to naive mice (Fig. $1 A-E)$ : acutely applied nicotine $(1 \mu \mathrm{M})$ increased the excitability of $\mathrm{MHb}$ neurons both across the entirety of $2 \mathrm{~s}$ depolarizing current steps $(n=4$ cells $/ 2$ mice, $\left.F_{(1,15)}=10.45, p<0.01\right)$ and during the initial $500 \mathrm{~ms}(n=4$ cells $/ 2$ mice, $F_{(1,15)}=12.59, p<0.01$; Fig. $\left.7 A, D, G\right)$. However,
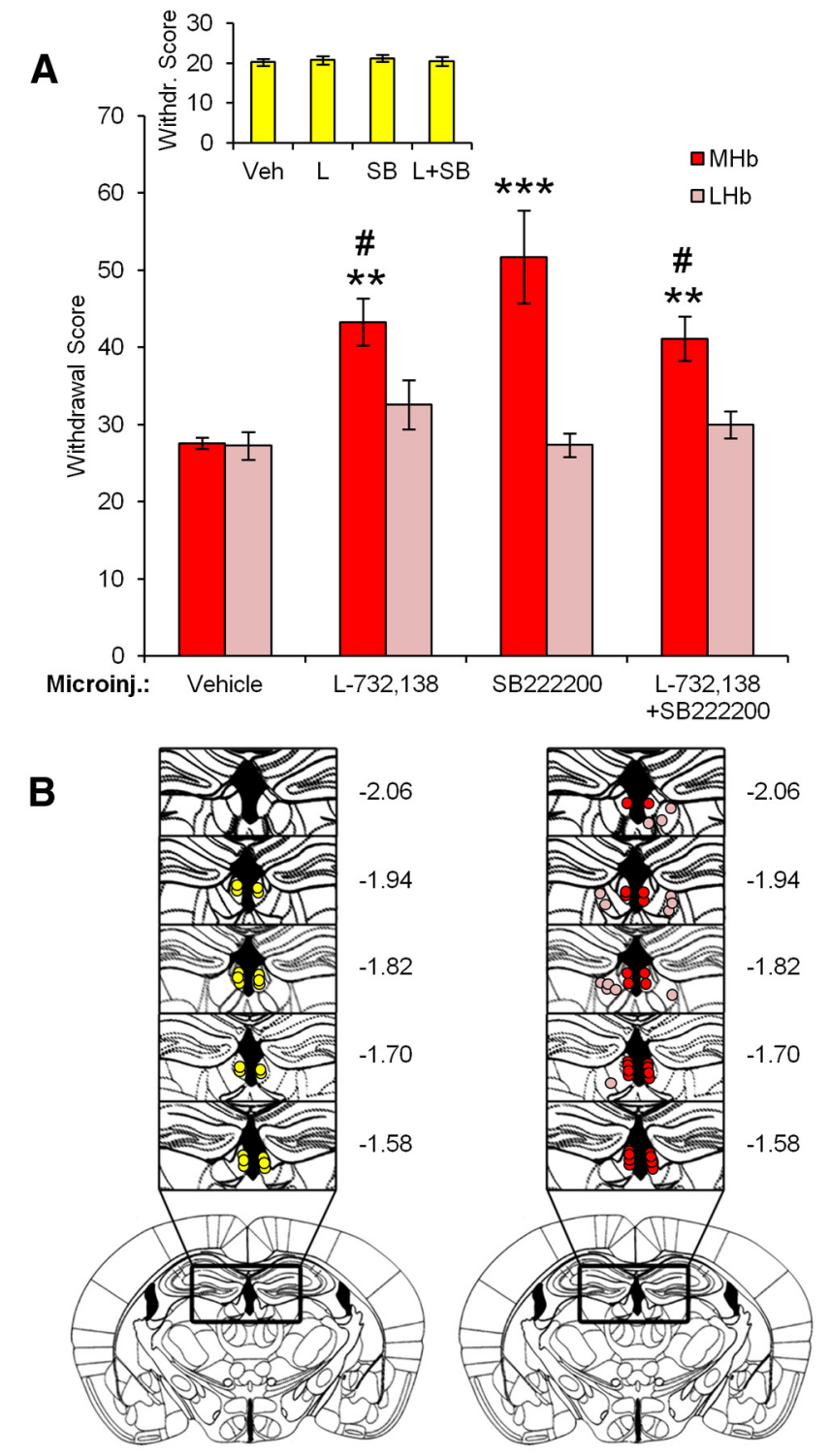

Chronic

Treatment:

Vehicle

Nicotine

Figure 6. Habenular microinjection of neurokinin receptor antagonists into the MHb precipitates somatic signs of withdrawal in mice chronically treated with nicotine. Mice were chronically treated with nicotine ( $8.4 \mathrm{mg} / \mathrm{kg} / \mathrm{d}, 2$ weeks) or vehicle via osmotic minipumps. $A$, In mice implanted with nicotine minipumps, the subsequent microinjection of L-732138, SB222200, or both drugs directly into the MHb increased the number of somatic signs observed during a 20 min examination period over that of vehicle-microinjected controls (red bars: $n=19$ for vehicle, $n=7$ for each drug-microinjected group). Conversely, analogous microinjections into the $\mathrm{LHb}$ of chronic nicotine-treated mice did not elicit elevated somatic signs over vehiclemicroinjected controls (pink bars: $n=6$ for vehicle, $n=5$ for each drug-microinjected group), nor did analogous microinjections into the $\mathrm{MHb}$ of mice implanted with vehicle minipumps (inset, yellow bars: $n=9$ for vehicle, $n=5$ for each drug-microinjected group). $\boldsymbol{B}$, Schematic representation of microinjection sites. All values are displayed as mean \pm SEM. ${ }^{* *} p<0.01$, ${ }^{* * *} p<0.001$ vs chronic nicotine/vehicle-microinjected group; \#p $<0.05$ vs chronic nicotine/ SB222200-microinjected group.

in brain slices from mice chronically treated with nicotine, the enhancement of excitability by acutely applied nicotine was attenuated (Fig. $7 B, E, H$ ). In particular, although a significant enhancement of excitability remained during the initial 500 ms of current steps ( $n=9$ cells $/ 5$ mice, $F_{(1,40)}=5.53, p<$ $0.05)$, the enhancement observed when averaged across the entire $2 \mathrm{~s}$ of the current steps was abolished $(n=9$ cells $/ 5$ mice, 
$p>0.05)$. This was not due to an altered baseline state in response to chronic nicotine, because baseline intrinsic excitability and $R_{\text {in }}$ were unchanged after chronic nicotine treatment (data not shown). Furthermore, to determine whether the reduction in nicotine's modulation of intrinsic excitability occurs through an effect on nAChRs or downstream, we tested whether the modulatory effect of NKB on intrinsic excitability is altered by chronic nicotine treatment. In brain slices from mice chronically treated with nicotine, the application of $100 \mathrm{nM}$ NKB significantly enhanced the excitability of MHb neurons (2 s step: $n=14$ cells $/ 9$ mice, $F_{(1,65)}=$ 30.77, $p<0.001$; initial $500 \mathrm{~ms}: n=14$ cells $/ 9$ mice, $F_{(1,65)}=111.8, p<0.001$; Fig. $7 C, F, I)$ in a fashion similar to that observed in naive mice (Fig. 5B,D,F). Last, vehicle or chronic nicotine treatment did not affect the reduction in $R_{\text {in }}$ by acute nicotine application (vehicle: baseline: $1.95 \pm 0.34 \mathrm{G} \Omega$ vs nicotine: $0.47 \pm$ $0.27 \mathrm{G} \Omega, n=4$ cells $/ 2$ mice, $p<0.05$; chronic nicotine: baseline: $2.06 \pm 0.39$ $\mathrm{G} \Omega$ vs nicotine: $0.83 \pm 0.27 \mathrm{G} \Omega, n=8$ cells/5 mice; $p<0.05$; Fig. $7 \mathrm{~J}, K)$ and NKB (100 nM) application did not alter $R_{\text {in }}$ in mice chronically treated with nicotine (baseline: $1.96 \pm 0.18 \mathrm{G} \Omega$ vs nicotine: $1.74 \pm 0.12 \mathrm{G} \Omega, n=13$ cells $/ 7$ mice, $p>$ 0.05 ; Fig. $7 L)$.

\section{Discussion}

\section{$\alpha 5$ nAChR subunit: evidence from} mouse behavior and GWAS

Our studies were guided by GWAS of the determinants of risk for nicotine dependence highlighting the involvement of the CHRNA5/CHRNA3/CHRNB4 $(\alpha 5, \alpha 3$ and $\beta 4$ ) gene cluster (Saccone et al., 2007; Berrettini et al., 2008; Bierut et al., 2008; Thorgeirsson et al., 2008; Berrettini and Doyle, 2012). In particular, we focused on the $\alpha 5 \mathrm{nAChR}$ subunit, the subunit most prominently featured in those GWAS (Amos et al., 2008; Berrettini et al., 2008; Thorgeirsson et al., 2008; Weiss et al., 2008; Wang et al., 2010). Previously we showed that the nAChRs in the MHb, including those that contain the $\alpha 5$ subunit, are crucial for the emergence of physical signs of withdrawal in mice chronically treated with nicotine (Salas et al., 2004a; Salas et al., 2009). Other evidence indicates that habenular $\alpha 5^{\star} \mathrm{nAChRs}$ regulate the aversive aspects of nicotine during self-administration (Fowler et al., 2011; Frahm et al., 2011). Our present results suggest a mechanism for these behaviors, that $\alpha 5^{\star}$ nAChRs mediate the enhancement of excitability by acutely applied nicotine through augmentation of neurokinin signaling. This occurs despite an opposing secondary effect of nicotine to reduce $R_{\text {in }}$, which sometimes manifested as decreased excitability at weaker stimuli, particularly in $\alpha 5$-null mice (Fig. $2 D,+10 \mathrm{pA}$

D Vehicle
B Chronic Nicotine

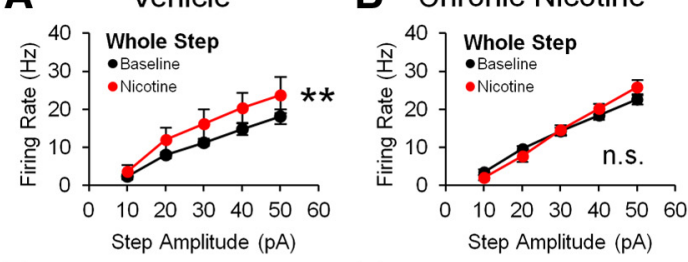

Baseline Nicotine

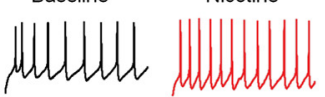

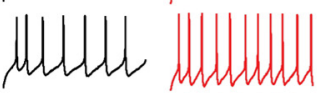

ulandu|
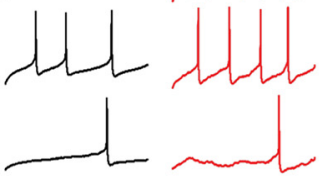

E Chronic Nicotine Initial $\mathbf{5 0 0} \mathbf{~ m s}$

Baseline Nicotine
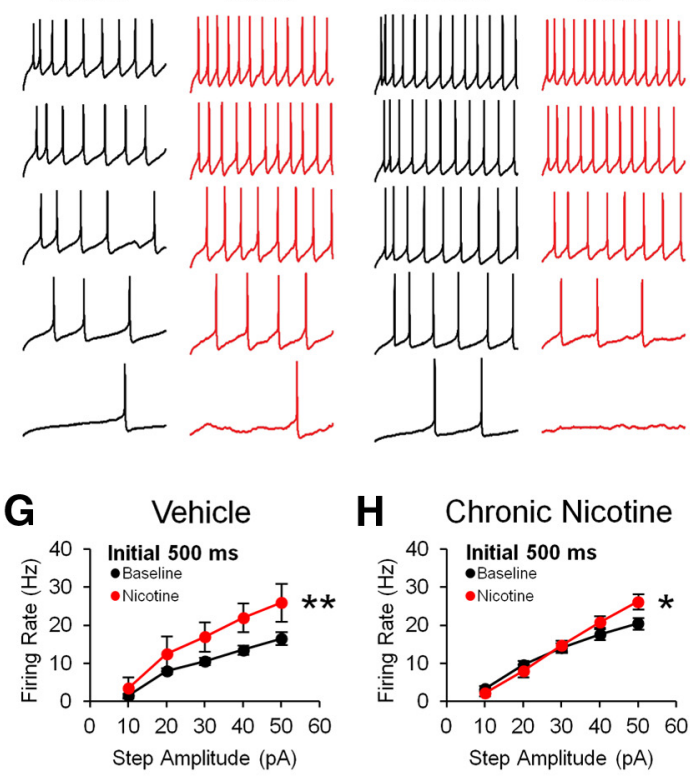

C Chronic Nicotine

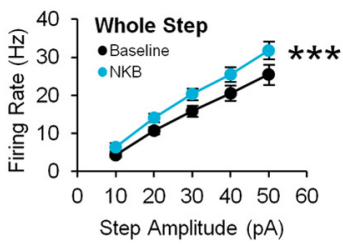

F Chronic Nicotine

Initial $\mathbf{5 0 0} \mathbf{~ m s}$

Baseline NKB

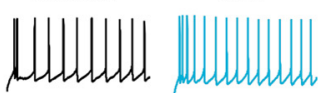

$+50 \mathrm{pA}$
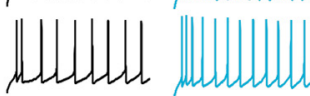

$+40 \mathrm{pA}$

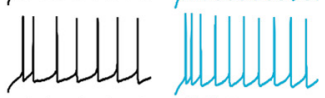

$+30 \mathrm{pA}$
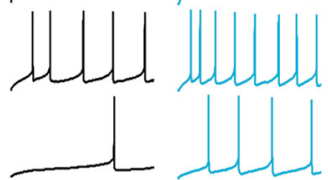

$+20 \mathrm{pA}$

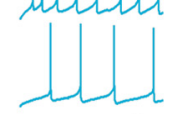

$+10 \mathrm{pA}$

Figure 7. Chronic nicotine treatment reduces the enhancement of excitability by nicotine. We investigated whether chronic nicotine exposure alters the acute ability of nicotine to modulate excitability. $\boldsymbol{A}, \mathbf{D}, \mathbf{G}$, In cells from mice chronically treated with vehicle, acute nicotine application $(1 \mu \mathrm{M})$ increased the number of action potentials elicited by $2 \mathrm{~s}$ depolarizing step currents both across the entire $2 \mathrm{~s}$ duration and during the initial $500 \mathrm{~ms}$ of the steps ( $n=4$ cells $/ 2$ mice). $\boldsymbol{B}, \boldsymbol{E}, \boldsymbol{H}$, However, after chronic nicotine treatment, acute nicotine application only slightly augmented the firing response to $2 \mathrm{~s}$ depolarizing current steps during the initial 500 ms of steps, but not across the entire $2 s$ duration ( $n=9$ cells $/ 5$ mice). $\boldsymbol{C}, \boldsymbol{F}, \boldsymbol{I}$, Ability of NKB ( $100 \mathrm{~nm}$ ) to enhance excitability remained after chronic nicotine treatment ( $n=14$ cells $/ 9$ mice). $\boldsymbol{J}, \boldsymbol{K}$, Acute nicotine application $(1 \mu \mathrm{m})$ reduced $R_{\text {in }}$ in neurons from both vehicle- and chronic nicotine-treated mice ( $n=4$ cells $/ 2$ mice, 8 cells $/ 5$ mice, respectively). $L$, NKB had no effect on $R_{\text {in }}$ after chronic nicotine treatment ( $n=13$ cells $/ 7$ mice). Scale bar indicates $20 \mathrm{mV} / 100 \mathrm{~ms}$. All values are displayed as mean $\pm S E M$. ${ }^{*} p<0.05 ;{ }^{* *} p<0.01 ;{ }^{* * *} p<0.001$.

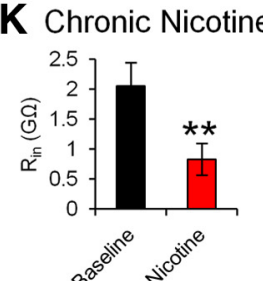

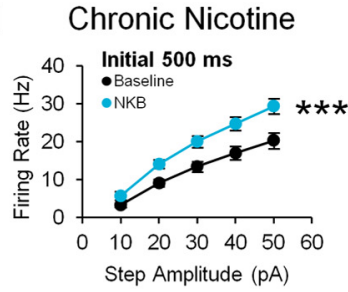

L Chronic Nicotine

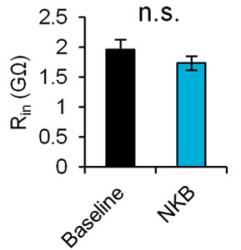

traces). Furthermore, we show that, under conditions of chronic nicotine exposure, the modulatory effect of nicotine to enhance excitability is attenuated.

\section{Neurokinins become mechanistic candidates for nicotine's effects}

Surprisingly, although removal of the $\beta 4$ subunit caused dramatic decreases in nAChR currents, this had no effect on nicotine-induced increases of intrinsic excitability. Nicotine's excitability enhancement also persisted through blockade of ionotropic glutamate and GABA receptors and these results led us to explore other possible routes for excitability modu- 


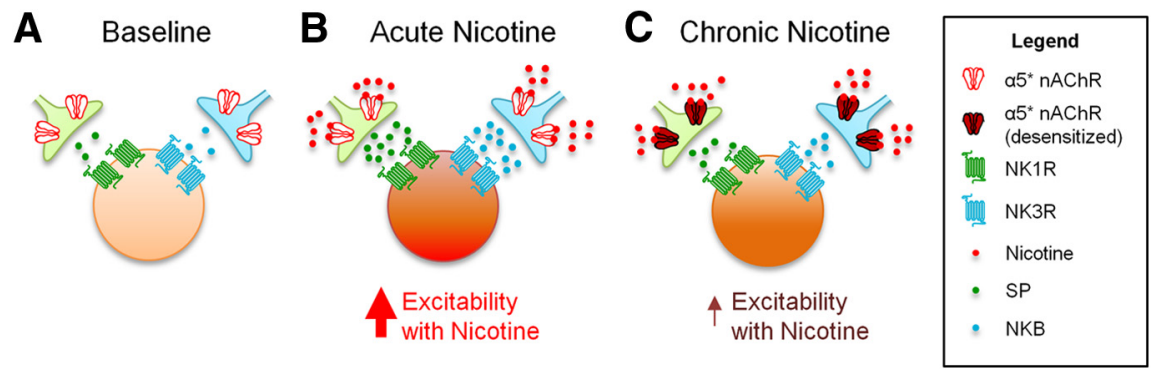

Figure 8. Model of modulation of intrinsic excitability by nicotine in the MHb. $A$, Under basal conditions, SP and NKB release onto $\mathrm{MHb}$ neurons modulates their intrinsic excitability. $\boldsymbol{B}$, Acutely applied nicotine binds to and activates $\alpha 5^{*} \mathrm{nAChRs}$ to promote SP and NKB release onto MHb neurons. The greater activation of NK1 and NK3 receptors by increased SP and NKB levels augments intrinsic excitability. $\boldsymbol{C}$, Chronic nicotine reduces the responsiveness of the $\alpha 5^{*} \mathrm{nAChRs}$, likely through desensitization of the $\mathrm{nAChRs}$ by chronic nicotine. Therefore, the acute ability of nicotine to enhance excitability is reduced when the drug is chronically present.

lation by nAChRs. Due to the high expression of neurokinins and their receptors in the $\mathrm{MHb}$ (Burgunder and Young, 1989; Yip and Chahl, 2001), as well as their analogous roles on excitability in the MHb and other brain areas (Norris et al., 1993; Ogier and Raggenbass, 2003; Budai et al., 2007), we chose to study this neuromodulatory system.

Nicotine's enhancement of excitability was blocked by preincubation with either NK1 or NK3 receptor antagonists. This result suggests a handful of scenarios, but the likeliest is that nicotine acts at different neuronal subpopulations within the $\mathrm{MHb}$, possibly due to the heterogenous mixture of neurons with differing expression of NK1 or NK3 receptors (Norris et al., 1993). Alternatively, nicotine may act at a heterogenous population of neurokinin synapses, for example, modulating the release of both SP and NKB. Regardless, only under blockade of both NK1 and NK3 receptors did we observe a complete abolishment of nicotine's enhancement of excitability, which provides further evidence that nicotine acts via a combination of mechanisms.

\section{Neurokinins participate in nicotine withdrawal behavior}

We reasoned that if nicotine's facilitation of neurokinin signaling is an important aspect of the nicotine-induced adaptations that take place in the brains of tobacco smokers, neurokinin receptor blockade during chronic nicotine treatment should mimic the cessation of nicotine intake and consequently lead to the emergence of withdrawal symptoms. We addressed this hypothesis by microinjecting antagonists for $\mathrm{NK} 1$ and NK3 receptors into the MHb and found that this triggered somatic withdrawal behavior in mice chronically treated with nicotine. For this reason, we believe that the removal of neurokinin signaling modulation by nicotine, mediated through $\alpha 5^{\star} \mathrm{nAChRs,}$ is a primary cause for the elimination of somatic nicotine withdrawal behavior in $\alpha 5$ null mice (Salas et al., 2009). As with most behavioral pharmacology experiments, it is difficult to control for the diffusion of drugs into nontargeted tissue. However, our attempt at eliciting withdrawal behavior by microinjection of neurokinin antagonists into the LHb, with the lack of an observed effect, further corroborates our model. $\beta 4$-null mice also lack withdrawal behavior (Salas et al., 2004a), but that behavior likely arises from the absence of nAChR currents (Fig. $3 A, B$ ) and the consequent deficiency of direct excitatory drive onto MHb neurons by nicotine. Therefore, in these two mouse lines, which both lack nicotine withdrawal behavior, different mechanisms may lead to convergent behavioral outcomes.

\section{Neuroadaptation during chronic nicotine exposure}

Chronic nicotine treatment reduced the nicotine-induced increase of neuronal excitability in the MHb. Additional details of how reduced responses to acute nicotine can arise under chronic nicotine exposure are suggested from currently known desensitization profiles of $\beta 2^{\star}$ and $\beta 4^{\star} \mathrm{nAChRs}$, particularly with respect to how densensitization is altered when the $\alpha 5$ subunit is present (Gerzanich et al., 1998). The inclusion of $\alpha 5$ into either $\beta 2^{*}$ or $\beta 4^{\star} \mathrm{nAChRs}$ increases both the rate and the magnitude of desensitization. However, in $\alpha 5 / \beta 2^{\star} \mathrm{nAChRs}$, the total amount of desensitization $(68 \%)$ is greater than that of $\alpha 5 / \beta 4^{\star} \mathrm{nAChRs} \mathrm{(41 \% ).} \mathrm{In} \mathrm{addition,}$ in $\beta 4^{\star}$ nAChRs lacking $\alpha 5$, desensitization is notably low compared with that in $\beta 2^{\star}$ nAChRs lacking $\alpha 5$ ( $21 \%$ vs $\left.46 \%\right)$. Therefore, the enhancement of intrinsic excitability by nicotine, which is abolished by the $\alpha 5$-null mutation and reduced by the $\beta 2$-null mutation, may be especially sensitive to $\mathrm{nAChR}$ desensitization in the chronic presence of nicotine. In addition, the incorporation of $\alpha 5$ subunits into nAChRs preferentially stabilizes the assembly of $\beta 2^{*}$ vs $\beta 4^{*} \mathrm{nAChRs}$ and greatly reduces the upregulation of the receptors in response to chronic nicotine treatment (Gahring and Rogers, 2010). Together, our results suggest that chronic nicotine attenuates nicotine's acute excitability modulation by desensitizing the nAChRs that modulate neurokinin signaling. Broadly, this might include both short and longer-lasting functional deficits. Further, the disruption of endogenous neurokinin signaling in the $\mathrm{MHb}$ of nicotinewithdrawn mice might ultimately trigger somatic withdrawal behavior. Consistent with this hypothesis, we find that NKBinduced excitability facilitation is maintained in mice chronically treated with nicotine.

\section{Neurokinins and neurokinin receptors in the $\mathrm{MHb}$}

$\mathrm{SP}$ and NKB are prominent endogenous ligands of NK1 and NK3 receptors (Pennefather et al., 2004). Although both receptors are activated by either ligand, SP preferentially activates NK1 receptors and NKB preferentially activates NK3 receptors. In contrast to the expression of $\mathrm{NKB}$, which is extremely dense and ubiquitous throughout the $\mathrm{MHb}$ (Lucas et al., 1992; Marksteiner et al., 1992; Lein et al., 2007), strong SP expression is confined to the dorsal one-third of the $\mathrm{MHb}$ (Lein et al., 2007; Aizawa et al., 2012). Both NK1 and NK3 receptors are strongly expressed in the cholinoceptive/cholinergic ventral two-thirds of the MHb (Langlois et al., 2001; Lein et al., 2007; Commons and Serock, 2009). For this study, we focused on neurons within the ventral two-thirds of the $\mathrm{MHb}$ because this subsection comprises the cholinoceptive and cholinergic $\mathrm{MHb}$ (Fig. 1A). Based on the expression pattern, the $\alpha 5^{\star}$ nAChRs modulating excitability might largely facilitate $\mathrm{NKB}$ release onto $\mathrm{MHb}$ neurons, with additional facilitation of SP release. Because of the anatomical expression, we suspect that the source of NKB onto the cholinoceptive/cholinergic $\mathrm{MHb}$ originates from local neurons in addition to neurons throughout the MHb. Conversely, the source of possible SP release onto the cholinoceptive/cholinergic $\mathrm{MHb}$ might be 
from the dorsal one-third of the $\mathrm{MHb}$, given evidence of dorsal to ventral projections with en passant synaptic boutons within the MHb (Kim and Chang, 2005). Presynaptic nAChRs can enhance neurotransmitter release in part by mediating a calcium influx (Dani and Bertrand, 2007). Heteromeric nAChRs that contain the $\alpha 5$ subunit have high calcium permeability (Gerzanich et al., 1998; Tapia et al., 2007) and thus could mediate a direct influence over neurotransmitter release.

\section{Synthesis and conclusion}

The present study supplies a potential mechanism for the emergence of nicotine withdrawal behaviors. We propose a novel interplay in the MHb between the nicotinic and neurokinin neuromodulatory systems. We showed that acutely applied nicotine exhibits bidirectional control over the intrinsic excitability of MHb neurons. In one direction, nicotine reduces $R_{\text {in }}$, likely via direct postsynaptic activation of $\beta 4^{*}$ nAChRs. In the opposite direction, which is the more dominant effect, nicotine enhances excitability via activation of $\alpha 5^{*}$ nAChRs that facilitate release of neurokinins (SP and NKB) onto both NK1 and NK3 receptors. Interestingly, blockade of habenular NK1 and NK3 receptors in mice chronically treated with nicotine precipitates physical symptoms of withdrawal. Lastly, chronic nicotine treatment mitigates the enhancement of excitability by acutely applied nicotine while sparing the enhancement of excitability by NKB application. Through these data, we present a model whereby nicotine acutely modulates neurokinin signaling via activation of $\alpha 5^{\star} \mathrm{nAChRs}$ to ultimately promote intrinsic neuronal excitability. Under chronic nicotine treatment, the neuromodulatory influence of nicotine is reduced at the level of nAChR function (Fig. 8). Nicotine's weakened modulation of intrinsic excitability may contribute to the unrewarding and aversive experience during nicotine withdrawal, despite the removal of an excitatory drive (nicotine) on a nucleus that encodes for aversion. Already, mechanisms involving neurokinins are reported to be involved in addiction to ethanol, cocaine, and opiates (Ripley et al., 2002; Davidson et al., 2004; George et al., 2008). Expansion of the present findings and similar investigative avenues may lead to neurokinin-based improved therapies for the treatment of dependence to nicotine and other drugs of abuse.

\section{References}

Aizawa H, Kobayashi M, Tanaka S, Fukai T, Okamoto H (2012) Molecular characterization of the subnuclei in rat habenula. J Comp Neurol 520: 4051-4066. CrossRef Medline

Alkondon M, Pereira EF, Wonnacott S, Albuquerque EX (1992) Blockade of nicotinic currents in hippocampal neurons defines methyllycaconitine as a potent and specific receptor antagonist. Mol Pharmacol 41:802-808. Medline

Amos CI, Wu X, Broderick P, Gorlov IP, Gu J, Eisen T, Dong Q, Zhang Q, Gu X, Vijayakrishnan J, Sullivan K, Matakidou A, Wang Y, Mills G, Doheny K, Tsai YY, Chen WV, Shete S, Spitz MR, Houlston RS (2008) Genomewide association scan of tag SNPs identifies a susceptibility locus for lung cancer at 15q25.1. Nat Genet 40:616-622. CrossRef Medline

Arvidsson U, Riedl M, Elde R, Meister B (1997) Vesicular acetylcholine transporter (VAChT) protein: a novel and unique marker for cholinergic neurons in the central and peripheral nervous systems. J Comp Neurol 378:454-467. CrossRef Medline

Benowitz NL (2009) Pharmacology of nicotine: addiction, smokinginduced disease, and therapeutics. Annu Rev Pharmacol Toxicol 49:5771. CrossRef Medline

Berrettini WH, Doyle GA (2012) The CHRNA5-A3-B4 gene cluster in nicotine addiction. Mol Psychiatry 17:856-866. CrossRef Medline

Berrettini W, Yuan X, Tozzi F, Song K, Francks C, Chilcoat H, Waterworth D,
Muglia P, Mooser V (2008) Alpha-5/alpha-3 nicotinic receptor subunit alleles increase risk for heavy smoking. Mol Psychiatry 13:368-373. CrossRef Medline

Bierut LJ, Stitzel JA, Wang JC, Hinrichs AL, Grucza RA, Xuei X, Saccone NL, Saccone SF, Bertelsen S, Fox L, Horton WJ, Breslau N, Budde J, Cloninger CR, Dick DM, Foroud T, Hatsukami D, Hesselbrock V, Johnson EO, Kramer J, et al. (2008) Variants in nicotinic receptors and risk for nicotine dependence. Am J Psychiatry 165:1163-1171. CrossRef Medline

Boulter J, O'Shea-Greenfield A, Duvoisin RM, Connolly JG, Wada E, Jensen A, Gardner PD, Ballivet M, Deneris ES, McKinnon D (1990) Alpha 3, alpha 5 , and beta 4 : three members of the rat neuronal nicotinic acetylcholine receptor-related gene family form a gene cluster. J Biol Chem 265:4472-4482. Medline

Budai D, Khasabov SG, Mantyh PW, Simone DA (2007) NK-1 receptors modulate the excitability of $\mathrm{ON}$ cells in the rostral ventromedial medulla. J Neurophysiol 97:1388-1395. Medline

Burgunder JM, Young WS 3rd (1989) Neurokinin B and substance P genes are co-expressed in a subset of neurons in the rat habenula. Neuropeptides 13:165-169. CrossRef Medline

Cascieri MA, Macleod AM, Underwood D, Shiao LL, Ber E, Sadowski S, Yu H, Merchant KJ, Swain CJ, Strader CD, Ming Fong T (1994) Characterization of the interaction of $\mathrm{N}$-acyl-L-tryptophan benzyl ester neurokinin antagonists with the human neurokinin-1 receptor. J Biol Chem 269: 6587-6591. Medline

Commons KG, Serock MR (2009) Coincidence of neurokinin 1 receptor with the vesicular glutamate transporter 3 (VGLUT3) in the rat forebrain. Neurosci Lett 464:188-192. CrossRef Medline

Copel C, Osorio N, Crest M, Gola M, Delmas P, Clerc N (2009) Activation of neurokinin 3 receptor increases $\mathrm{Na}(\mathrm{v}) 1.9$ current in enteric neurons. J Physiol 587:1461-1479. CrossRef Medline

Couturier S, Erkman L, Valera S, Rungger D, Bertrand S, Boulter J, Ballivet M, Bertrand D (1990) Alpha 5, alpha 3, and non-alpha 3. Three clustered avian genes encoding neuronal nicotinic acetylcholine receptor-related subunits. J Biol Chem 265:17560-17567. Medline

Dani JA, Bertrand D (2007) Nicotinic acetylcholine receptors and nicotinic cholinergic mechanisms of the central nervous system. Annu Rev Pharmacol Toxicol 47:699-729. CrossRef Medline

Davidson C, Lee TH, Ellinwood EH (2004) The NK(1) receptor antagonist WIN51708 reduces sensitization after chronic cocaine. Eur J Pharmacol 499:355-356. CrossRef Medline

De Biasi M, Dani JA (2011) Reward, addiction, withdrawal to nicotine. Annu Rev Neurosci 34:105-130. CrossRef Medline

Duga S, Soldà G, Asselta R, Bonati MT, Dalprà L, Malcovati M, Tenchini ML (2001) Characterization of the genomic structure of the human neuronal nicotinic acetylcholine receptor CHRNA5/A3/B4 gene cluster and identification of novel intragenic polymorphisms. J Hum Genet 46:640-648. CrossRef Medline

Ebner K, Singewald N (2006) The role of substance P in stress and anxiety responses. Amino Acids 31:251-272. CrossRef Medline

Edwards FA, Gibb AJ, Colquhoun D (1992) ATP receptor-mediated synaptic currents in the central nervous system. Nature 359:144-147. CrossRef Medline

Fowler CD, Lu Q, Johnson PM, Marks MJ, Kenny PJ (2011) Habenular alpha5 nicotinic receptor subunit signalling controls nicotine intake. Nature 471:597-601. CrossRef Medline

Frahm S, Slimak MA, Ferrarese L, Santos-Torres J, Antolin-Fontes B, Auer S, Filkin S, Pons S, Fontaine JF, Tsetlin V, Maskos U, Ibañez-Tallon I (2011) Aversion to nicotine is regulated by the balanced activity of beta4 and alpha5 nicotinic receptor subunits in the medial habenula. Neuron 70: 522-535. CrossRef Medline

Gahring LC, Rogers SW (2010) Nicotinic receptor subunit alpha5 modifies assembly, up-regulation, and response to pro-inflammatory cytokines. J Biol Chem 285:26049-26057. CrossRef Medline

George DT, Gilman J, Hersh J, Thorsell A, Herion D, Geyer C, Peng X, Kielbasa W, Rawlings R, Brandt JE, Gehlert DR, Tauscher JT, Hunt SP, Hommer D, Heilig M (2008) Neurokinin 1 receptor antagonism as a possible therapy for alcoholism. Science 319:1536-1539. CrossRef Medline

Gerzanich V, Wang F, Kuryatov A, Lindstrom J (1998) alpha 5 Subunit alters desensitization, pharmacology, $\mathrm{Ca}++$ permeability and $\mathrm{Ca}++$ modulation of human neuronal alpha 3 nicotinic receptors. J Pharmacol Exp Ther 286:311-320. Medline 
Goldhill J, Angel I (1998) Mechanism of tachykinin NK3 receptor-mediated colonic ion transport in the guinea pig. Eur J Pharmacol 363:161-168. CrossRef Medline

Gottesfeld Z (1983) Origin and distribution of noradrenergic innervation in the habenula: a neurochemical study. Brain Res 275:299-304. CrossRef Medline

Gray R, Rajan AS, Radcliffe KA, Yakehiro M, Dani JA (1996) Hippocampal synaptic transmission enhanced by low concentrations of nicotine. Nature 383:713-716. CrossRef Medline

Kim U, Chang SY (2005) Dendritic morphology, local circuitry, and intrinsic electrophysiology of neurons in the rat medial and lateral habenular nuclei of the epithalamus. J Comp Neurol 483:236-250. CrossRef Medline

Kinsey AM, Wainwright A, Heavens R, Sirinathsinghji DJ, Oliver KR (2001) Distribution of 5-ht(5A), 5-ht(5B), 5-ht(6) and 5-HT(7) receptor mRNAs in the rat brain. Brain Res Mol Brain Res 88:194-198. CrossRef Medline

Kopp J, Xu ZQ, Zhang X, Pedrazzini T, Herzog H, Kresse A, Wong H, Walsh JH, Hökfelt T (2002) Expression of the neuropeptide Y Y1 receptor in the CNS of rat and of wild-type and Y1 receptor knock-out mice. Focus on immunohistochemical localization. Neuroscience 111:443-532. CrossRef Medline

Lammel S, Lim BK, Ran C, Huang KW, Betley MJ, Tye KM, Deisseroth K, Malenka RC (2012) Input-specific control of reward and aversion in the ventral tegmental area. Nature 491:212-217. CrossRef Medline

Langlois X, Wintmolders C, te Riele P, Leysen JE, Jurzak M (2001) Detailed distribution of Neurokinin 3 receptors in the rat, guinea pig and gerbil brain: a comparative autoradiographic study. Neuropharmacology 40: 242-253. CrossRef Medline

Lein ES, Hawrylycz MJ, Ao N, Ayres M, Bensinger A, Bernard A, Boe AF, Boguski MS, Brockway KS, Byrnes EJ, Chen L, Chen L, Chen TM, Chin MC, Chong J, Crook BE, Czaplinska A, Dang CN, Datta S, Dee NR, et al. (2007) Genome-wide atlas of gene expression in the adult mouse brain. Nature 445:168-176. CrossRef Medline

Léna C, Changeux JP (1997) Role of Ca2+ ions in nicotinic facilitation of GABA release in mouse thalamus. J Neurosci 17:576-585. Medline

Lucas LR, Hurley DL, Krause JE, Harlan RE (1992) Localization of the tachykinin neurokinin B precursor peptide in rat brain by immunocytochemistry and in situ hybridization. Neuroscience 51:317-345. CrossRef Medline

Marksteiner J, Sperk G, Krause JE (1992) Distribution of neurons expressing neurokinin $\mathrm{B}$ in the rat brain: immunohistochemistry and in situ hybridization. J Comp Neurol 317:341-356. CrossRef Medline

Matsumoto M, Hikosaka O (2007) Lateral habenula as a source of negative reward signals in dopamine neurons. Nature 447:1111-1115. CrossRef Medline

Matsumoto M, Hikosaka O (2009) Representation of negative motivational value in the primate lateral habenula. Nat Neurosci 12:77-84. CrossRef Medline

McCormick DA, Prince DA (1987) Acetylcholine causes rapid nicotinic excitation in the medial habenular nucleus of guinea pig, in vitro. J Neurosci 7:742-752. Medline

McGehee DS, Heath MJ, Gelber S, Devay P, Role LW (1995) Nicotine enhancement of fast excitatory synaptic transmission in CNS by presynaptic receptors. Science 269:1692-1696. CrossRef Medline

Merighi A, Salio C, Ferrini F, Lossi L (2011) Neuromodulatory function of neuropeptides in the normal CNS. J Chem Neuroanat 42:276-287. CrossRef Medline

Norris SK, Boden PR, Woodruff GN (1993) Agonists selective for tachykinin NK1 and NK3 receptors excite subpopulations of neurons in the rat medial habenula nucleus in vitro. Eur J Pharmacol 234:223-228. CrossRef Medline

Ogier R, Raggenbass M (2003) Action of tachykinins in the rat hippocampus: modulation of inhibitory synaptic transmission. Eur J Neurosci 17: 2639-2647. CrossRef Medline

Palma E, Bertrand S, Binzoni T, Bertrand D (1996) Neuronal nicotinic alpha 7 receptor expressed in Xenopus oocytes presents five putative binding sites for methyllycaconitine. J Physiol 491:151-161. Medline

Papke RL, Dwoskin LP, Crooks PA, Zheng G, Zhang Z, McIntosh JM, Stokes C (2008) Extending the analysis of nicotinic receptor antagonists with the study of alpha6 nicotinic receptor subunit chimeras. Neuropharmacology 54:1189-1200. CrossRef Medline
Pennefather JN, Lecci A, Candenas ML, Patak E, Pinto FM, Maggi CA (2004) Tachykinins and tachykinin receptors: a growing family. Life Sci 74:14451463. CrossRef Medline

Qin C, Luo M (2009) Neurochemical phenotypes of the afferent and efferent projections of the mouse medial habenula. Neuroscience 161:827837. CrossRef Medline

Quick MW, Ceballos RM, Kasten M, McIntosh JM, Lester RA (1999) Alpha3beta4 subunit-containing nicotinic receptors dominate function in rat medial habenula neurons. Neuropharmacology 38:769-783. CrossRef Medline

Ren J, Qin C, Hu F, Tan J, Qiu L, Zhao S, Feng G, Luo M (2011) Habenula "cholinergic" neurons co-release glutamate and acetylcholine and activate postsynaptic neurons via distinct transmission modes. Neuron 69: 445-452. CrossRef Medline

Ripley TL, Gadd CA, De Felipe C, Hunt SP, Stephens DN (2002) Lack of self-administration and behavioural sensitisation to morphine, but not cocaine, in mice lacking NK1 receptors. Neuropharmacology 43:1258 1268. CrossRef Medline

Saccone SF, Hinrichs AL, Saccone NL, Chase GA, Konvicka K, Madden PA, Breslau N, Johnson EO, Hatsukami D, Pomerleau O, Swan GE, Goate AM, Rutter J, Bertelsen S, Fox L, Fugman D, Martin NG, Montgomery GW, Wang JC, Ballinger DG, et al. (2007) Cholinergic nicotinic receptor genes implicated in a nicotine dependence association study targeting 348 candidate genes with 3713 SNPs. Hum Mol Genet 16:36-49. CrossRef Medline

Salas R, Pieri F, De Biasi M (2004a) Decreased signs of nicotine withdrawal in mice null for the beta4 nicotinic acetylcholine receptor subunit. J Neurosci 24:10035-10039. CrossRef Medline

Salas R, Cook KD, Bassetto L, De Biasi M (2004b) The alpha3 and beta4 nicotinic acetylcholine receptor subunits are necessary for nicotineinduced seizures and hypolocomotion in mice. Neuropharmacology 47: 401-407. CrossRef Medline

Salas R, Sturm R, Boulter J, De Biasi M (2009) Nicotinic receptors in the habenulo-interpeduncular system are necessary for nicotine withdrawal in mice. J Neurosci 29:3014-3018. CrossRef Medline

Sarau HM, Griswold DE, Bush B, Potts W, Sandhu P, Lundberg D, Foley JJ, Schmidt DB, Webb EF, Martin LD, Legos JJ, Whitmore RG, Barone FC, Medhurst AD, Luttmann MA, Giardina GA, Hay DW (2000) Nonpeptide tachykinin receptor antagonists. II. Pharmacological and pharmacokinetic profile of SB-222200, a central nervous system penetrant, potent and selective NK-3 receptor antagonist. J Pharmacol Exp Ther 295:373-381. Medline

Schütz B, Damadzic R, Weihe E, Eiden LE (2003) Identification of a region from the human cholinergic gene locus that targets expression of the vesicular acetylcholine transporter to a subset of neurons in the medial habenular nucleus in transgenic mice. J Neurochem 87:1174-1183. CrossRef Medline

Sculptoreanu A, de Groat WC (2007) Neurokinins enhance excitability in capsaicin-responsive DRG neurons. Exp Neurol 205:92-100. CrossRef Medline

Sheffield EB, Quick MW, Lester RA (2000) Nicotinic acetylcholine receptor subunit mRNA expression and channel function in medial habenula neurons. Neuropharmacology 39:2591-2603. CrossRef Medline

Sutherland RJ (1982) The dorsal diencephalic conduction system: a review of the anatomy and functions of the habenular complex. Neurosci Biobehav Rev 6:1-13. CrossRef Medline

Tapia L, Kuryatov A, Lindstrom J (2007) Ca2+ permeability of the (alpha4)3(beta2)2 stoichiometry greatly exceeds that of (alpha4)2(beta2)3 human acetylcholine receptors. Mol Pharmacol 71:769-776. Medline

Thorgeirsson TE, Geller F, Sulem P, Rafnar T, Wiste A, Magnusson KP, Manolescu A, Thorleifsson G, Stefansson H, Ingason A, Stacey SN, Bergthorsson JT, Thorlacius S, Gudmundsson J, Jonsson T, Jakobsdottir M, Saemundsdottir J, Olafsdottir O, Gudmundsson LJ, Bjornsdottir G, et al. (2008) A variant associated with nicotine dependence, lung cancer and peripheral arterial disease. Nature 452:638-642. CrossRef Medline

Ullian EM, McIntosh JM, Sargent PB (1997) Rapid synaptic transmission in the avian ciliary ganglion is mediated by two distinct classes of nicotinic receptors. J Neurosci 17:7210-7219. Medline

Wang J, Spitz MR, Amos CI, Wilkinson AV, Wu X, Shete S (2010) Mediating effects of smoking and chronic obstructive pulmonary disease 
on the relation between the CHRNA5-A3 genetic locus and lung cancer risk. Cancer 116:3458-3462. CrossRef Medline

Weiss RB, Baker TB, Cannon DS, von Niederhausern A, Dunn DM, Matsunami N, Singh NA, Baird L, Coon H, McMahon WM, Piper ME, Fiore MC, Scholand MB, Connett JE, Kanner RE, Gahring LC, Rogers SW, Hoidal JR, Leppert MF (2008) A candidate gene approach identifies the CHRNA5-A3-B4 region as a risk factor for age-dependent nicotine addiction. PLoS Genet 4:e1000125. CrossRef Medline

Xia YF, Margolis EB, Hjelmstad GO (2010) Substance P inhibits GABAB receptor signalling in the ventral tegmental area. J Physiol 588:1541-1549. CrossRef Medline

Xu W, Gelber S, Orr-Urtreger A, Armstrong D, Lewis RA, Ou CN, Patrick
J, Role L, De Biasi M, Beaudet AL (1999) Megacystis, mydriasis, and ion channel defect in mice lacking the alpha3 neuronal nicotinic acetylcholine receptor. Proc Natl Acad Sci U S A 96:5746-5751. CrossRef Medline

Yip J, Chahl LA (2001) Localization of NK1 and NK3 receptors in guineapig brain. Regul Pept 98:55-62. CrossRef Medline

Yu CR, Role LW (1998) Functional contribution of the alpha7 subunit to multiple subtypes of nicotinic receptors in embryonic chick sympathetic neurones. J Physiol 509:651-665. CrossRef Medline

Zhang ZW, Coggan JS, Berg DK (1996) Synaptic currents generated by neuronal acetylcholine receptors sensitive to alpha-bungarotoxin. Neuron 17:1231-1240. CrossRef Medline 